\title{
A Preliminary Assessment of Plug-In Hybrid Electric Vehicles on Wind Energy Markets
}

Technical Report NREL/TP-620-39729

April 2006

W. Short and P. Denholm

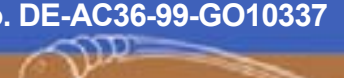




\section{A Preliminary Assessment of Plug-In Hybrid Electric Vehicles on Wind Energy Markets}

W. Short and P. Denholm

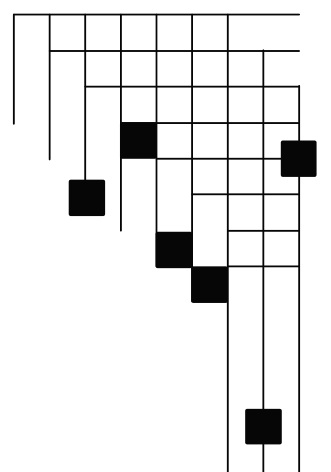

Prepared under Task No. WUA7.1000 


\section{NOTICE}

This report was prepared as an account of work sponsored by an agency of the United States government. Neither the United States government nor any agency thereof, nor any of their employees, makes any warranty, express or implied, or assumes any legal liability or responsibility for the accuracy, completeness, or usefulness of any information, apparatus, product, or process disclosed, or represents that its use would not infringe privately owned rights. Reference herein to any specific commercial product, process, or service by trade name, trademark, manufacturer, or otherwise does not necessarily constitute or imply its endorsement, recommendation, or favoring by the United States government or any agency thereof. The views and opinions of authors expressed herein do not necessarily state or reflect those of the United States government or any agency thereof.

Available electronically at http://www.osti.gov/bridge

Available for a processing fee to U.S. Department of Energy and its contractors, in paper, from:

U.S. Department of Energy

Office of Scientific and Technical Information

P.O. Box 62

Oak Ridge, TN 37831-0062

phone: 865.576 .8401

fax: 865.576 .5728

email: mailto:reports@adonis.osti.gov

Available for sale to the public, in paper, from:

U.S. Department of Commerce

National Technical Information Service

5285 Port Royal Road

Springfield, VA 22161

phone: 800.553 .6847

fax: 703.605.6900

email: orders@ntis.fedworld.gov

online ordering: http://www.ntis.gov/ordering.htm 


\section{TABLE OF CONTENTS}

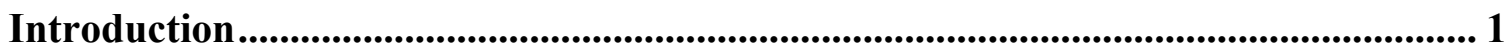

Technology Status ........................................................................................................................ 1

Description of the WinDS Model and Base Case .......................................................... 4

Addition of PHEVs to the WinDS Model ..................................................................... 7

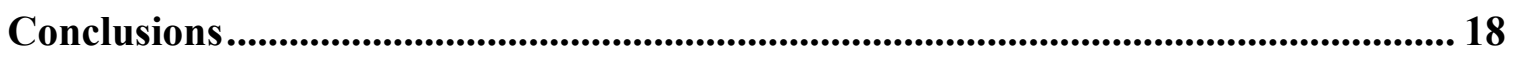

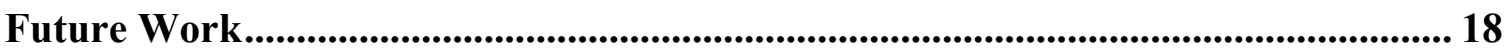

Appendix 1: Effects of Increasing PHEV Reserve Capacity via "Engine-On"

Capability....................................................................................................................... 20

Appendix 2: Summary of Data Used in WinDS........................................................... 21 


\section{Introduction}

The United States currently faces some of its most daunting energy challenges in recent history. And the challenge with the largest visibility and immediate consumer impact is the high price of gasoline and natural gas. A little less visible, but still strong in the national consciousness, is the issue of oil availability. The nation's dependence on foreign imports (especially from the unstable Middle East), along with vulnerabilities from international terrorism, heightens the immediacy of the oil availability issue. Finally, on top of these oil supply/price issues, the United States faces the strong possibility that its use of fossil fuels is damaging the Earth's climate.

This report examines a measure that may potentially reduce oil use and also more than proportionately reduce carbon emissions from vehicles. The authors present a very preliminary analysis of plug-in hybrid electric vehicles (PHEVs) that can be charged from or discharged to the grid. These vehicles have the potential to reduce gasoline consumption and carbon emissions from vehicles, as well as improve the viability of renewable energy technologies with variable resource availability. This paper is an assessment of the synergisms between plug-in hybrid electric vehicles and wind energy. The authors examine two bounding cases that illuminate this potential synergism.

\section{Technology Status}

The following discusses the issues associated with wind energy and PHEV technologies.

\section{Wind}

The use of wind energy for electricity generation has grown dramatically with decreasing costs and improved performance of wind turbines, increasing fossil fuel costs, and growing environmental concerns. The United States has a large wind power resource base, exceeding the current installed electricity generation capacity from all sources. The development and use of this power resource is limited by a number of factors, including the location of high-value wind resources, the resource variability of wind energy, and the relatively low availability (measured as amount of electricity actually generated/maximum electricity available, if operated continuously at full-rated power) of this generation source, compared to conventional alternatives.

Variability in wind output implies limited predictability; high natural ramp rates; and, often, limited coincidence with peak demand. These factors can restrict the ultimate penetration of wind power into traditional electric power systems. The high reliability required by such systems dictates that ample capacity is always available and that conventional generators are able to follow the variations in loads, forced outages, and variable supplies like wind. Where wind power adds to these capacity requirements, it usually incurs additional costs. 
One possible solution to the problem of variable wind output is energy storage - the application of any of several technologies that can store electricity when it is not needed - and that can deliver stored electricity when demand is high, or renewable output is low. The United States currently has about $20 \mathrm{GW}$ of pumped hydroelectric storage in place, with further expansion restricted by lack of available sites, environmental issues and high cost. While there are a few other options, such as compressed air energy storage, ${ }^{1}$ these technologies all add significantly to the cost of electricity to be stored.

The optimal solution for wind would be coupling it with a low-cost source of energy storage (or dispatchable load) that is perhaps already in existence for some other purpose. The emergence of "plug-in" hybrid electric vehicles may provide this significant opportunity.

\section{PHEVS}

The emergence of hybrid-electric vehicles (HEVs) provides a potentially significant enabling technology for variable-generation sources such as wind energy. As currently offered by several major auto manufacturers, hybrid-electric vehicles add a battery and electric motor to an internal-combustion (IC) engine. This combination increases fuel economy by allowing the IC engine to operate more efficiently, shutting off the engine during stops, and recapturing otherwise discarded kinetic energy through regenerative braking. While the overall efficiency is increased, all of the energy is still derived from petroleum. However, some of the drive energy could be derived from grid electricity by increasing the size of the HEV's battery and by adding external charging capability.

A "plug-in" HEV (PHEV) may also be designated by its effective "all-electric" range, such as PHEV-20, referring to a vehicle that may be driven 20 miles from its batteries. Beyond this range, the vehicle operates as a conventional HEV. For the average driver, the use of a relatively small battery delivers much of the benefits of a pure electric vehicle, without the disadvantages of prohibitive cost or limited range.

The economic incentive for drivers to use electricity as fuel is the comparatively low cost. Assuming a vehicle efficiency of $3.4 \mathrm{mile} / \mathrm{kWh}$, and $85 \%$ charging efficiency, a PHEV would need about $9-10 \mathrm{kWh}$ to drive the 25 to 30 miles provided by a gallon of

\footnotetext{
${ }^{1}$ Denholm, P, 2006. "Improving the Technical, Environmental, and Social Performance of Wind Energy Systems Using Biomass-Based Energy Storage" Renewable Energy. 31, 1355-1370.
} 
gasoline. ${ }^{2}$ However, unlike the $\$ 2 /$ gallon cost of gasoline, today's cost of this electricity would be less than $\$ 1$ in most locations, and could be less than 50 cents when using offpeak power at preferential rates.

The large-scale deployment of PHEVs may be possible with continued improvements and decreasing costs of existing HEV technology, as well as advanced batteries. A study by the Electric Power Research Institute (EPRI) found a significant potential market for PHEVs, depending on vehicle cost and the future cost of petroleum. ${ }^{3}$ In this paper, the authors do not directly address the economics of PHEVs. Rather, they examine the implications of an assumed high level of penetration of PHEVs into the light-duty vehicle (LDV) market.

\section{Vehicle to Grid (V2G) Capability}

Many researchers have noted that the maximum economic benefit of PHEVs may be derived by adding "vehicle-to-grid" (V2G) capability, where the vehicle can discharge, as well as charge. ${ }^{4}$ This capability adds potentially significant revenue to the owner by providing high-value electric system services to the grid, such as regulation and spinning reserve. These services are described in more detail in the next section.

To maximize the economic value of the PHEV to the consumer, it is almost certain that the charging and discharging vehicle will be controlled directly or indirectly by the utility system. External control allows the vehicle to be charged with the lowest-cost electricity, and also allows the vehicle to provide high-value ancillary services. With direct control, the utility would send a signal to an individual vehicle or a group of vehicles. Such a concept is already in use through other load-control programs in place for water heaters, air conditioners, etc. The direct control could also be established through an aggregator that sells the aggregated demand of many individual vehicles to a utility, regional system operator, or a regional wholesale electricity market.

Under the second option - indirect control - the vehicle would respond intelligently to real-time price signals or some other price schedule to buy or sell electricity at the appropriate time. In either control scheme, the vehicles would be effectively "dispatched" to provide the most economical charging and discharging.

\footnotetext{
${ }^{2}$ This efficiency is probably higher than a U.S. fleet of PHEVs, resembling the current fleet of new lightduty vehicles. A study by EPRI found an electric-drive efficiency of 2.3, 2.7, and $4.0 \mathrm{miles} / \mathrm{kWh}$ for three reference vehicles characterized as full-sized SUVs, mid-size SUVs, and compact cars (see Reference 3). The same study cites the fuel economy of a reference (conventional IC engine) mid-sized SUV at 22.2 MPG. Given the current new-car fleet average fuel economy of about 25 mpg (AEO 2006, Table A7), the equivalent PHEV fleet electric drive efficiency would be closer to the mid-size SUV fuel economy, perhaps around 2.9 miles $/ \mathrm{kWh}$.

${ }^{3}$ Electric Power Research Institute, 2002. " Comparing the Benefits and Impacts of Hybrid Electric Vehicle Options for Compact Sedan and Sport Utility Vehicles " EPRI, Palo Alto, Calif,, 1006891

${ }^{4}$ Kempton, W. and J. Tomic, 2005. "Vehicle-to-grid power fundamentals: Calculating capacity and net revenue." Journal of Power Sources, 144(1): 268-279.
} 


\section{Description of the WinDS Model and Base Case}

To assess the benefits and impacts of PHEVs on the electric grid, the authors used the Wind Deployment System (WinDS) model. The (WinDS) model is a computer model originally designed to evaluate the potential for wind energy generation in the United States. To do this, the model optimizes the regional expansion of electric generation and transmission capacity in the continental United States during the next 50 years. The model "competes" wind and conventional alternatives (fossil, nuclear), considering the requirements of the electric power systems, as well as the economic and technical characteristics of each technology. The model includes region-specific data for wind, and also considers, in detail, the statistical impacts of wind-resource variability.

WinDS minimizes system-wide costs of meeting electric loads, reserve requirements, and emission constraints by building and operating new generators and transmission in 26 two-year periods from 2000 to 2050. The primary outputs of WinDS are the amount of capacity and generation of each type of prime mover - coal, gas combined cycle, gas combustion turbine, nuclear, wind, etc. - in each year of each 2-year period. Additional documentation about the model structure and treatment of wind and conventional generation resources is available at www.nrel.gov/analysis/winds. Electricity demand forecasts, as well as forecasted costs of conventional generation and fuels used in the WinDS model, are based largely on the U.S. Energy Information Administration's Annual Energy Outlook (AEO), which is updated annually. Aside from the assumptions regarding market penetration of plug-in hybrids, the results presented in this document are based on the 2005 AEO, summarized in Appendix 2.

Figures 1 and 2 present the results from a base case WinDS run through 2050 that does not include PHEVs. This base case represents a "business-as-usual" scenario for U.S. energy policies in effect in spring 2005 (i.e. no carbon constraints, etc.) 


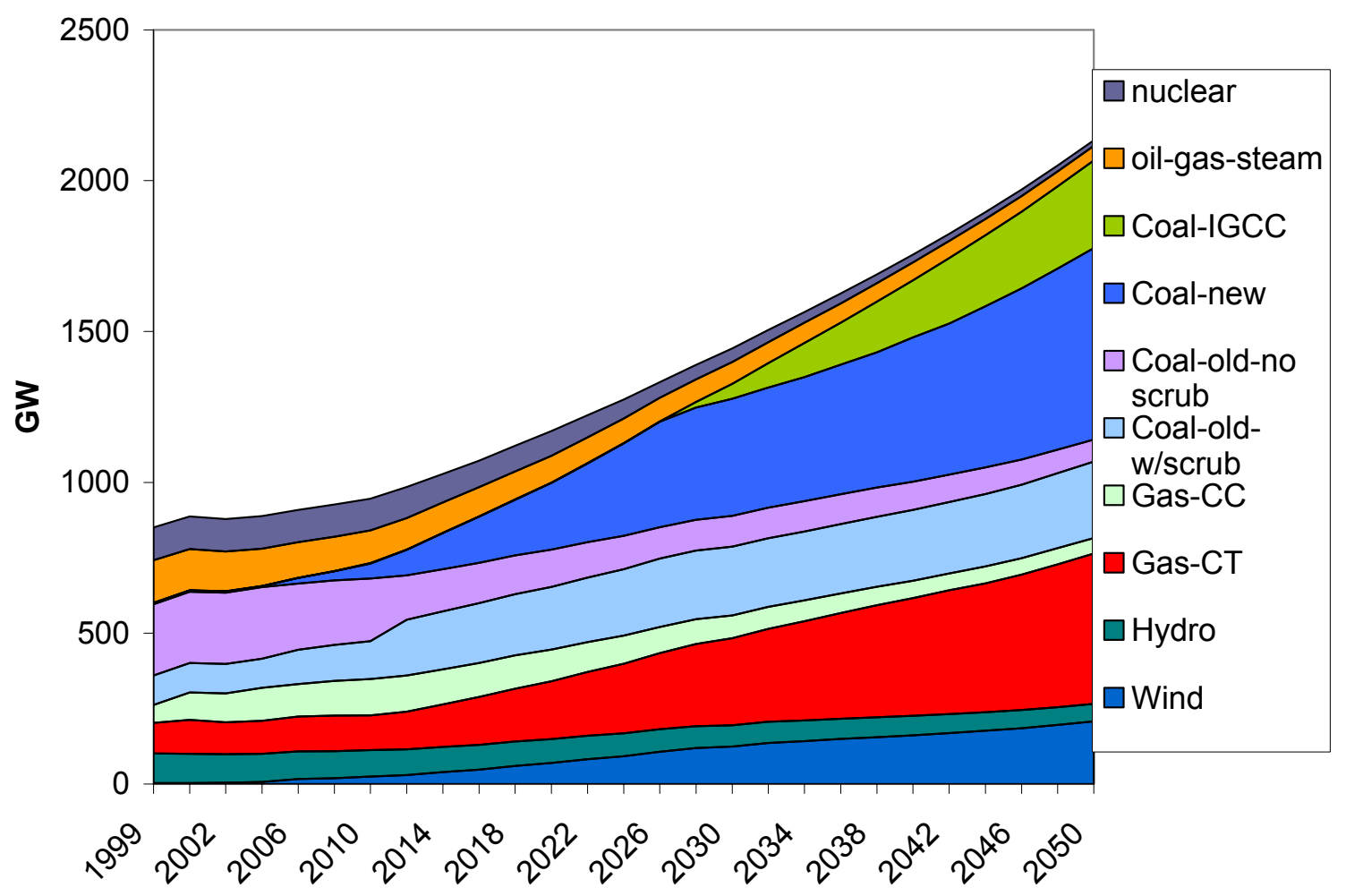

Figure 1: Base Case Projection of U.S. Electric System Capacity from WinDS

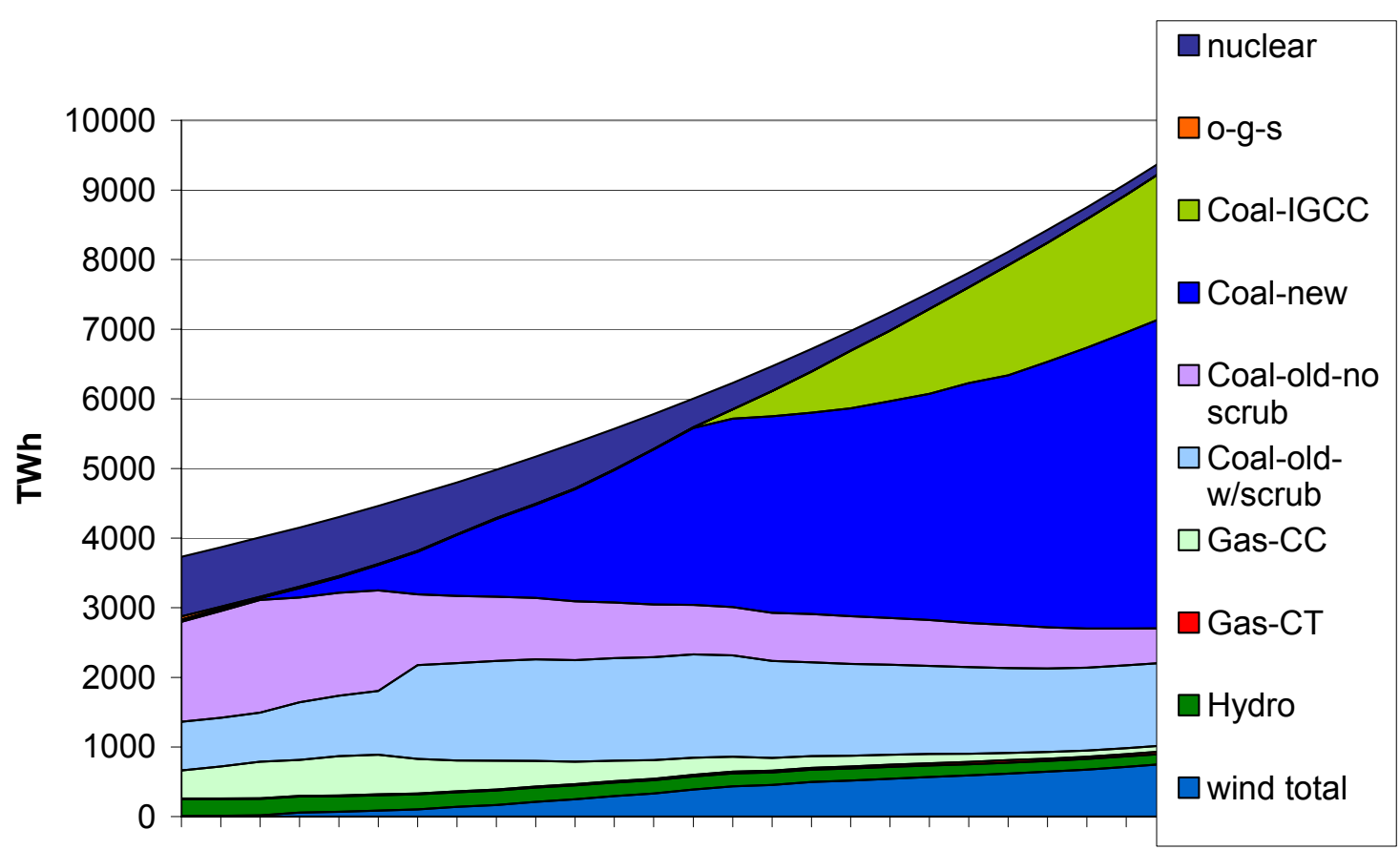

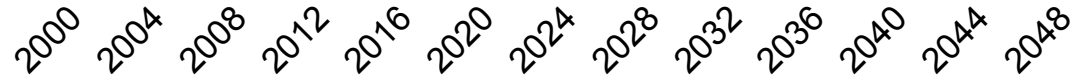

Figure 2: Base Case Projection of U.S. Electric System Generation from WinDS 
Figure 1 provides total installed capacity by type, while Figure 2 provides generation by type. The base case projects that there will be significant growth in wind capacity-more than $200 \mathrm{GW}$ by 2050 . However, this value is much less than the technically exploitable wind resources in the United States of more than 7,000 GW (includes Class 3 wind), ${ }^{5}$ and provides less than $10 \%$ of the nation's electricity. Wind deployment in this business-asusual case is constrained by a range of factors including environmental, land-use, and siting issues; transmission constraints; low conventional fuel costs; and the resource variability of wind. The addition of PHEVs to the model did not relax any of the basic constraints on wind energy development, with the exception of reducing the impact of wind-resource variability via the capacity available in PHEV batteries.

The variability in wind generation precludes wind from contributing fully to the reserve margins required by utilities to ensure continuous system reliability. Within WinDS, grid reliability is captured by two constraints on planning reserves and operating reserves. Planning reserves ensure adequate capacity during all hours of the year. Typical systems require a "peak reserve margin" of $10 \%-18 \%$. This means a utility must have in place 10\%-18\% more capacity than their projected peak power demand for the year. This ensures reliability against generator or transmission failure, underestimates of peak demand, or extreme weather events. WinDS estimates planning reserves directly through a system constraint - the aggregated installed capacity multiplied by a reliability factor must exceed the peak demand multiplied by the peak reserve margin for each North American Electric Reliability Council (NERC) region. Due to the resource variability of wind generation, only a small fraction of a wind farm's nameplate capacity is usually counted toward the planning reserve margin requirement. In fact, as wind penetrates further into an electric grid, this "capacity credit" for wind generally declines, especially if the wind farms are developed near each other, i.e. if their output is well correlated. With its 358 wind-supply regions, WinDS can assess the correlation between the outputs of different wind farms and, therefore, more accurately calculate the capacity credit for each addition of wind capacity installed.

Operation reserves include several types of reserves in place to respond to short-term unscheduled demand fluctuations, or generator/other system failure. Operating reserve represents generators that can be started or ramped up quickly. There are several categories of operating reserves, often referred to as ancillary services. WinDS does not model each of these individual services directly, but instead aggregates them into a single operating-reserve constraint. This constraint requires the system to have a certain amount of "quick-start" and "spinning" capacity in the system. Quick-start capacity includes combustion turbines and hydroelectricity, while spinning capacity represents other partly loaded fossil and/or hydroelectric plants. The introduction of wind power into a grid can increase these operation-reserve requirements, due to the variability in wind generation.

While WinDS simulates many other factors that influence the market potential of wind power, e.g., transmission requirements, this report focuses on the impacts of wind output variability, because these can be partly mitigated by PHEVs connected to the grid.

\footnotetext{
${ }^{5}$ Denholm, P. and W. Short, 2006. "Documentation of WinDS Base Case Data" Available at: http://www.nrel.gov/analysis/winds/pdfs/winds_data.pdf (see Appendix A, Wind Resource Dataset)
} 
PHEVs can supply some of the planning and operating reserves required by the grid, which relieves some of the burden on wind.

To assess the impact of PHEVs on the market potential of wind power, it was necessary to modify the WinDS model to allow PHEVs to contribute both planning and operatingreserve capacity. This was done by adding the capacity available from the stock of PHEVs that have penetrated the market (see Figure 1) to the reserves in the planning and operating-reserve constraints of WinDS.

PHEVs can also supply regulation reserve to the electric grid. This ancillary service assists the grid in following the second-by-second variations in load. Regulation reserve can be a fairly expensive form of reserve with costs that regularly exceed $\$ 35$ per hour for each MW made available. ${ }^{6}$ Regulation reserve could be easily provided by PHEV batteries, because energy draws are minuscule with charging and discharging reversing every few seconds as loads fluctuate up and down. Studies have shown that PHEVs provide significantly more value in the form of regulation reserve than they do in the form of planning reserves or operating reserves. ${ }^{7,8}$ When evaluating the economics of PHEVs, consideration of regulation reserve value is critical. The authors do not consider it here for two reasons: 1) the authors aren't considering the economics of PHEVs (they simply assume a PHEV penetration scenario), and 2) wind power does not significantly impact regulation reserve requirements and, therefore, is not impacted by the regulation reserve available through PHEVs.

\section{Addition of PHEVs to the WinDS Model}

\section{PHEV Market Penetration}

In this preliminary study, the authors assumed PHEVs penetrate the market under the following scenario:

It is assumed that the total light-duty vehicle fleet in 2050 is 448 million vehicles - based on Energy Information Administration (EIA) projections of 309 million vehicles in $2025^{9}$ - and a $1.5 \%$ annual growth rate from 2025 to 2050 . It is assumed that PHEVs are introduced in 2008, and achieve a 50\% market share of the light-duty vehicle stock by

\footnotetext{
${ }^{6}$ Kirby, B., 2004. "Frequency Regulation Basics and Trends," ORNL/TM-2004/291. Available at www.ornl.gov/ webworks/cppr/y2001/rpt/122302.pdf

${ }^{7}$ Brooks, A. and T. Gage, 2001. "Integration of Electric Drive Vehicles with the Electric Power Grid -- a New Value Stream" 18th International Electric Vehicle Symposium (EVS-18), Berlin, World Electric Vehicle Association (WEVA). Available at www.acpropulsion.com/EVS18/ACP V2G_EVS18.pdf

${ }^{8}$ Kempton \& Tomic, 2005.

${ }^{9}$ Energy Information Administration, 2005. "Supplement Tables to the Annual Energy Outlook 2005" Available at http://www.eia.doe.gov/oiaf/archive/aeo05/supplement/index.html (Table 48)
} 
2050 as shown in Figure 1. The market penetration shape in Figure 3 is based on a market-diffusion "S-curve" 10 .

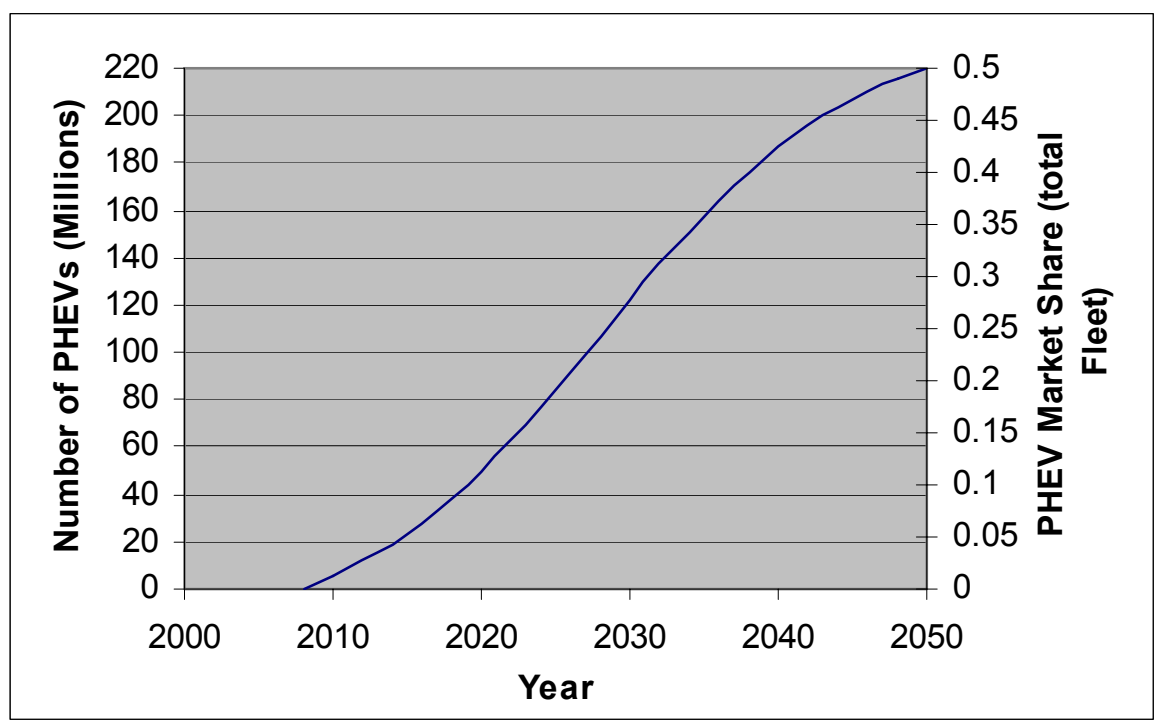

Figure 3: PHEV Total Market-Share Assumption

The actual penetration of PHEVs will depend on the relative economics of PHEVs and other vehicle alternatives. This preliminary study does not address these economics. It is our intent simply to show the potential benefits of a relatively high level of PHEV market penetration on the use of wind power in the electric sector. In the near future, the authors hope to expand this analysis to assess the feasibility of the market penetration shown in Figure 3 by evaluating the relative economics of PHEVs.

\section{PHEV Technical Characteristics}

The analysis assumed that the average PHEV achieves an electric-drive efficiency of 3.4 miles $/ \mathrm{kWh}(0.29 \mathrm{kWh} / \mathrm{mile})$, and a charging efficiency of $85 \% .{ }^{11}$ This corresponds to a "plug efficiency" of 2.9 miles/kWh, a value which can be compared directly to a conventional fuel efficiency typically measured in miles/gallon. This value is based on estimates by EPRI for a mid-sized passenger vehicle that corresponds to a conventional vehicle with an average fuel economy of about $25 \mathrm{mpg} .{ }^{12}$ The authors also assumed that two different sizes of PHEVs are available: a PHEV-20 with a $5.9 \mathrm{kWh}$ battery, or a PHEV-60 with a $17.7 \mathrm{kWh}$ battery. In all cases in this document, battery capacity is

${ }^{10}$ Bass model: $\frac{1-e^{-(p+q) \bullet T}}{q}$ where $\mathrm{T}$ is the year, $\mathrm{p}$ and $\mathrm{q}$ are values that characterize the S-curve

$$
1+\frac{q}{p} \bullet e^{-(p+q) \bullet T}
$$

shape.

${ }^{11}$ Electric-drive efficiency (miles/kWh) is similar to "conventional" fuel efficiency, typically measured in miles/gallon.

12 Electric Power Research Institute, 2001. "Comparing the Benefits and Impact of Hybrid Electric Vehicle Options," EPRI, Palo Alto, Calif,, 10003496892. 
considered useful capacity, meaning the battery can be cycled over its full-rated capacity (5.9 or $17.7 \mathrm{kWh}$ ) without affecting useful life. Finally, the authors assumed that all PHEVs have V2G capability.

[The analysis assumed that PHEVs operate in "blended mode," where the vehicle operates in "EV-only" mode at low speeds, but requires some operation of the IC engine at high speeds. This reduces the size of the EV components and reduces overall cost, at the expense of reduced "electric-only" miles. Combining this assumption with typical driving patterns produces an average "electric miles traveled" of about 15 miles per day for a PHEV-20, and about 25 miles per day for a PHEV-60. ${ }^{13}$ ]

As a result of these assumptions, the overall reduction in petroleum use is about $50 \%$ for the PHEV-20 and about 80\% for the PHEV-60, compared to a conventional IC engine vehicle. It should be noted that a significant fraction of the fuel use benefits are derived from the hybridization of the vehicle. Converting the "average" vehicle to a HEV-0 (nonplug-in hybrid) may improve the fuel economy by about $25 \%{ }^{14}$

\section{PHEV Capacity Credit}

Several assumptions were made to establish the total capacity credit that utilities might apply to PHEVs that provide operating and planning reserve capacity. Estimating the effective "capacity" provided by a fleet of PHEVs is somewhat challenging, given the important time-sensitive (how many cars are plugged in and when) nature of PHEV use. The power capacity of an individual PHEV is a function of many factors: whether or not it is plugged in, the capacity of the plug circuit, the amount of time vehicle discharge is required, the vehicle useful-battery capacity, the state of charge of the battery at the initiation of discharge, and whether or not the IC engine may be turned on to provide electricity. For a reasonable number of vehicles deployed, each of these factors can be expressed as a distribution, or average, which may or may not vary over time.

PHEV plug-in factor: Data from the U.S. Department of Transportation ${ }^{15}$ indicates that only a small fraction of vehicles (fewer than $20 \%$ ) are on the road at any one time. While it is likely that the fraction of vehicles on the road will vary significantly during the course of a day, the most important value is the fraction plugged in during peak periods, because the planning reserve constraint is based on capacity required at peak. The authors chose a plug-in factor of 50\%. Because the vehicle-to-grid services are required at all times - including times when a high percentage of vehicles will be away from their home base - this high plug-in factor may imply that charging facilities will have to be made available at workplaces and perhaps shopping locations.

\footnotetext{
${ }^{13}$ EPRI, 2002.

14 Ibid.

${ }^{15}$ U.S. Department of Transportation, 2004. "2001 National Household Travel Survey." Available at http://nhts.ornl.gov/2001/index.shtml
} 
Maximum circuit capacity: A PHEV could have an internal electric system capacity that exceeds $100 \mathrm{~kW} .{ }^{16}$ However, not all of this capacity will be accessible to the grid for planning and operating reserves. Nearly all PHEVs will be plugged in to conventional residential and commercial electric circuits at $120 \mathrm{~V}$ or $240 \mathrm{~V}$. At these voltages, the line capacity is the bottleneck on power flow to and from the grid. However, many customers (such as fleet owners) may choose to utilize much higher capacity circuits for maximum economic benefits. The overall range of likely circuits is $2.4 \mathrm{~kW}(120 \mathrm{~V} @ 20 \mathrm{~A})$ to perhaps $24 \mathrm{~kW}(240 \mathrm{~V} @ 100 \mathrm{~A})$. The authors chose9.6 kW (e.g., 240 V@ $90 \mathrm{~A})$ as their "average" value for PHEV grid connection. ${ }^{17}$

Energy constraint: The continuous power rating of a PHEV is limited by the stored energy in its batteries. A fully charged PHEV-20 with a $5.9 \mathrm{kWh}$ (useful capacity) battery could provide $9.6 \mathrm{~kW}$ for 0.6 hours. Operating-reserve events are typically shorter than this period; however, for planning reserves, utilities will likely require dependable discharge times of several hours or more. The amount of discharge time required (and the state of charge of the battery) heavily influences how much capacity credit may be given to the battery fleet as a whole, particularly if generation from the IC engine is restricted.

Figure 4 illustrates the potential capacity credit for a single PHEV, as a function of the required discharge time. In this case, the vehicle is assumed to have a fully charged battery, and is connected to a $9.6 \mathrm{~kW}$ circuit. For short-term events ( 30 minutes or less for a PHEV-20), the vehicle is line-limited, illustrated by the flat line at the upper lefthand side of the vehicle capacity curve. For longer-term events requiring hours of continuous discharge, the size of the battery limits the capacity credit that may be applied to an individual vehicle.

\footnotetext{
${ }^{16} 2006$ Toyota Motor Sales, U.S.A., Inc. Available at: http://toyota.com/highlander/specs_hybrid.html

${ }^{17}$ New high-capacity $240 \mathrm{~V}$ circuits for parking lot and fleet-charging stations would cost the same as new $120 \mathrm{~V}$ circuits see EPRI, 2002.
} 


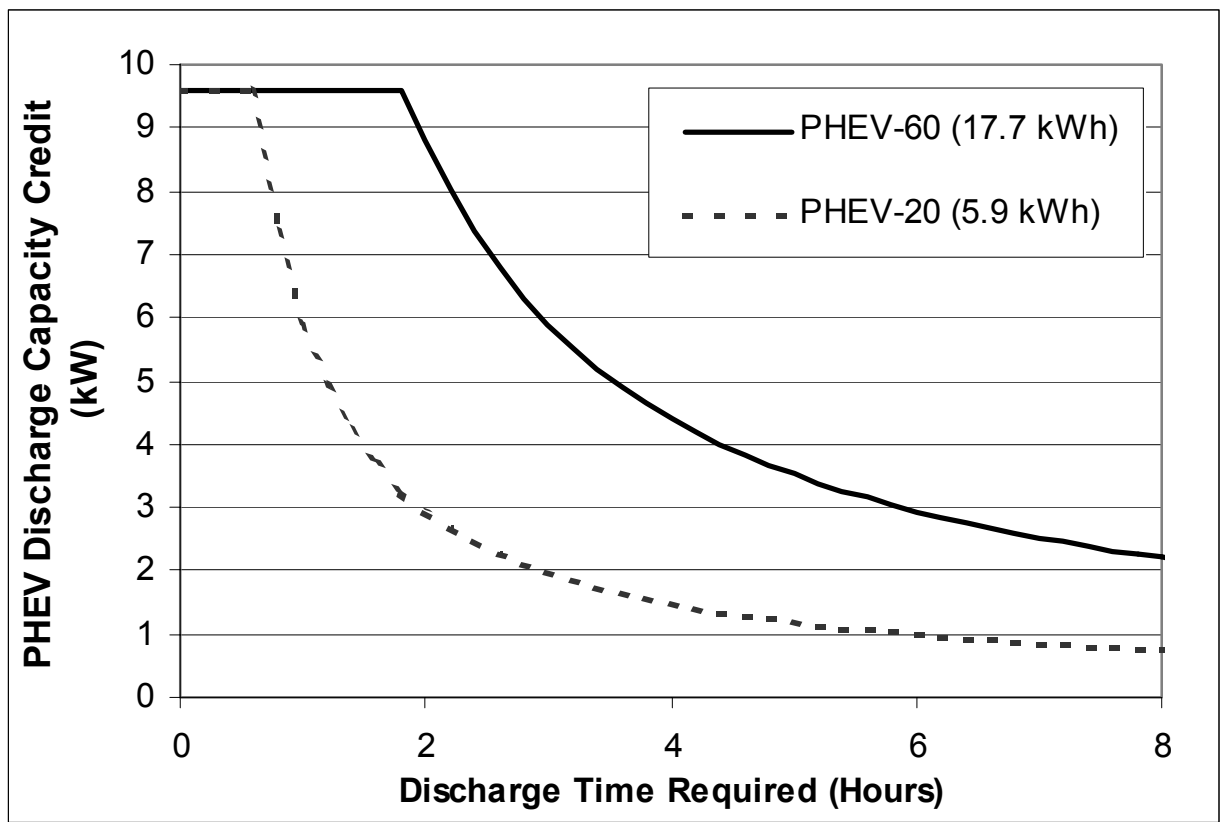

Figure 4: Capacity of a PHEV as a Function of Discharge Time Required (fully charged battery, $9.6 \mathrm{~kW}$ plug circuit assumed)

The analysis assumed a discharge requirement of 30 minutes for operating reserves ${ }^{18}$ and 4 hours for planning reserves.

The final capacity value, representing the total capacity for the average PHEV, can be calculated according to the formula:

Vehicle Capacity $=$ The minimum of

Line capacity

OR

Battery energy $(\mathrm{kWh}) * \mathrm{SOC} * \%$ plugged in / Discharge Time Required (hours)

The authors established two cases where the fleet is comprised only of either PHEV-20s or PHEV-60s. They assumed that the PHEV-60, with its larger useful battery capacity, would generally have a higher state of charge at the beginning of a reserve need. In both cases, the vehicles must provide energy only from the battery - the IC engine cannot be used as a stationary generator. Table 1 provides the PHEV capacity assumptions for the two cases.

\footnotetext{
${ }^{18}$ Kirby, B., 2003. "Spinning Reserve From Responsive Loads" ORNL/TM 2003/19. Available at: http://certs.lbl.gov/PDF/Spinning_Reserves.pdf
} 
Table 1: Effective Capacity of a PHEV for Two Evaluated Cases

\begin{tabular}{|l|c|c|}
\hline Parameter & PHEV-20 Case & PHEV-60 Case \\
\hline Line Capacity (kW) & 9.6 & 9.6 \\
\hline \% Plugged in & 50 & 50 \\
\hline $\begin{array}{l}\text { Battery Size (useful capacity - } \\
\text { kWh) }\end{array}$ & 5.9 & 17.7 \\
\hline Battery SOC (\%) & 60 & 70 \\
\hline $\begin{array}{l}\text { Operating Reserve Capacity } \\
\text { (kW per PHEV) }\end{array}$ & 3.5 & 5.8 \\
\hline $\begin{array}{l}\text { Planning Reserve Capacity (kW } \\
\text { per PHEV) }\end{array}$ & 0.4 & 1.5 \\
\hline
\end{tabular}

The effective system-wide capacity provided by a fleet of PHEVs can be calculated by multiplying the per-vehicle capacity calculated in Equation 1 by the number of vehicles. The assumptions for vehicle penetration in Figure 3 and the assumptions in Table 1 provide the effective PHEV reserve capacity, illustrated in Figure 5 as a function of time.

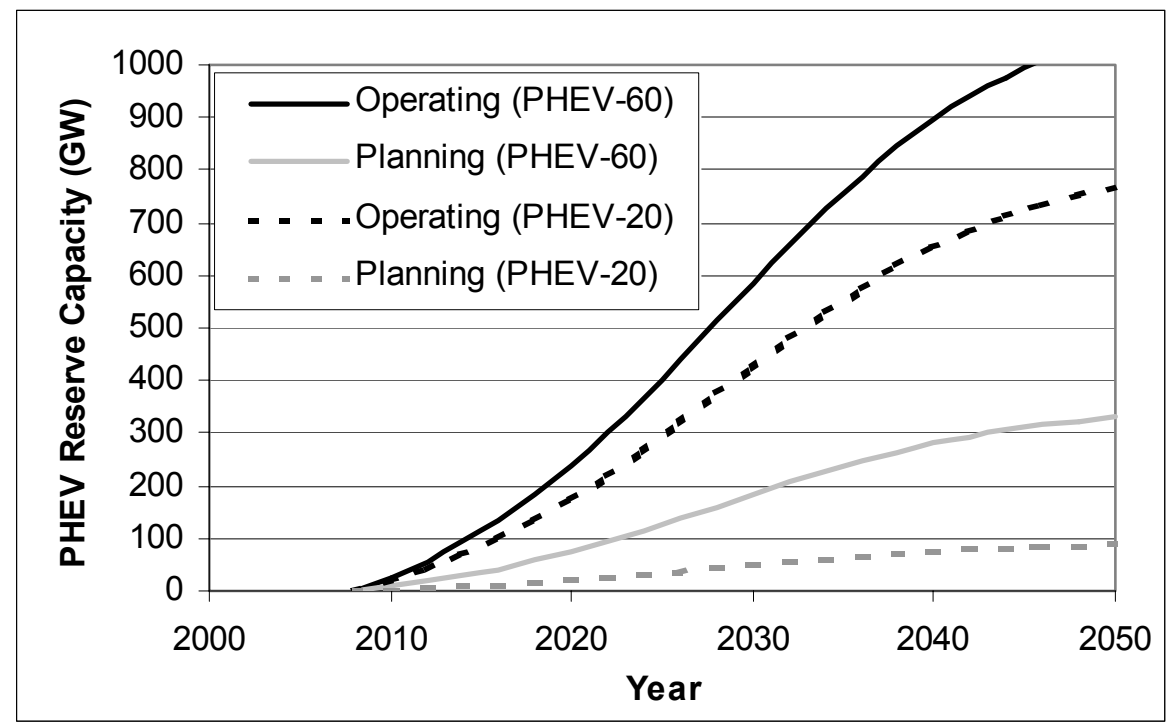

Figure 5: PHEV Capacity Assumptions

\section{PHEV Charging Requirements}

Based on the stated PHEV performance assumptions, the daily charging requirement of the PHEV-20 is $5.2 \mathrm{kWh}$ per day, while the PHEV-60 requires $8.6 \mathrm{kWh}$ per day. The analysis assumes that the majority of the PHEVs are charged in the evening off-peak $(60 \%)$, with some additional charging during the shoulder periods (30\% morning shoulder -7 a.m. to 1 p.m.; and $10 \%$ evening shoulder -6 p.m. to 10 p.m.). This 
distribution was based roughly on the results from the "V2G-load" tool developed by the NREL Energy Analysis Office to assess the impacts of utility dispatchable load. ${ }^{19}$

\section{Results}

\section{PHEV Impacts on the Electric Sector}

As discussed previously, in the base case that does not consider PHEVs, WinDS estimates cost-effective wind installations to be about $208 \mathrm{GW}$ by 2050 . Wind installations increase with the addition of PHEVs and the reserve capacity they bring to the grid. In the PHEV-20 case, WinDS projects an increase in wind installations to 235 GW by 2050; while, in the PHEV-60 case, the WinDS model produced a final installed wind capacity of $443 \mathrm{GW}$. The wind installations in the PHEV-60 case represent a $\sim 110 \%$ increase over the base case installations, with wind providing about $16 \%$ of the total U.S. electric generation (1554 TWh out of $10082 \mathrm{TWh}$ total electric generation).

Figures 6 and 7 show the capacity and generation of all generator types in the PHEV-60 Case.

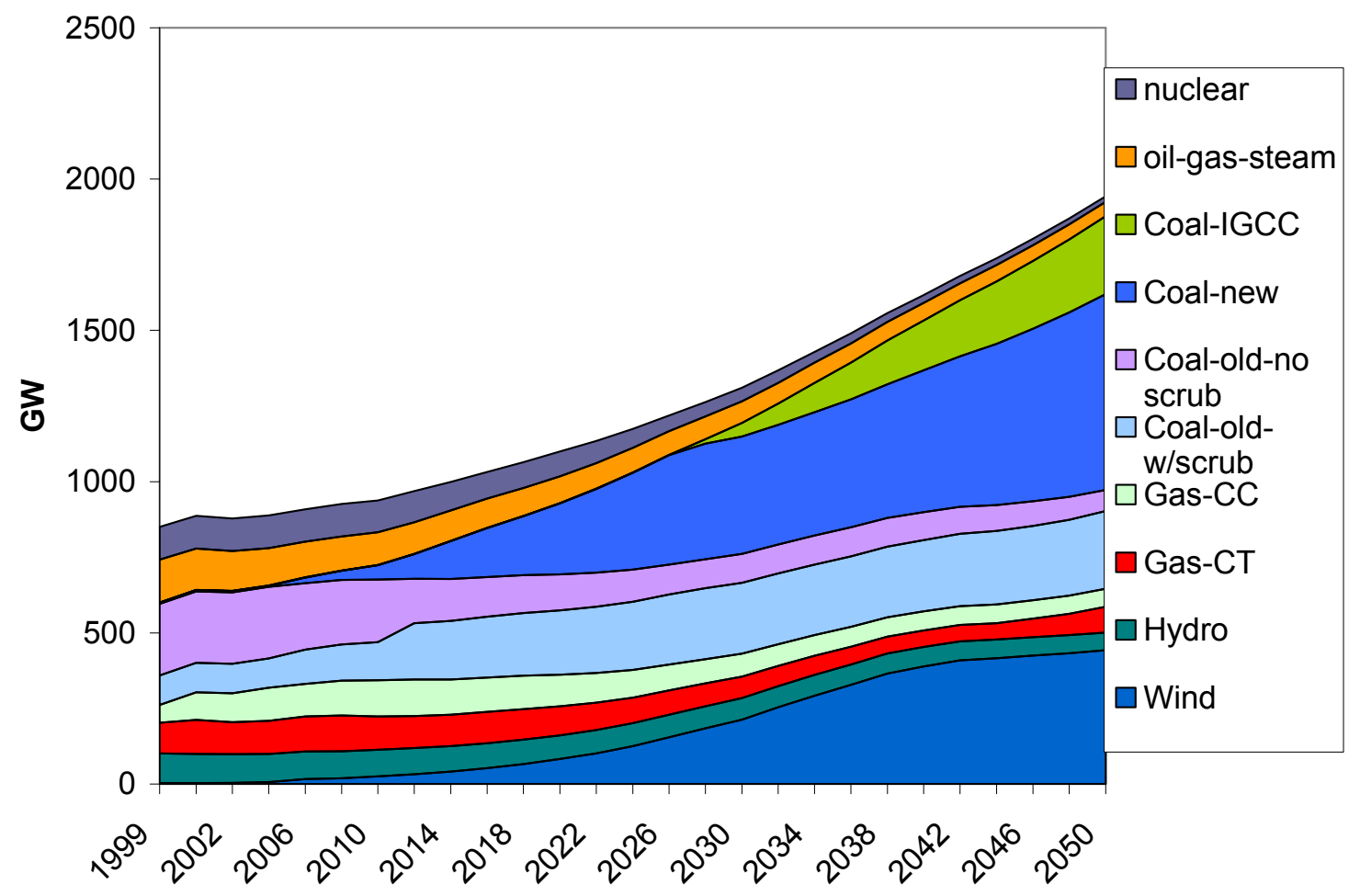

Figure 6: Capacity Expansion in the WinDS PHEV-60 Case

\footnotetext{
${ }^{19}$ Denholm, P. and W. Short, 2006. "An Evaluation of Utility System Impacts and Benefits of Plug-In Hybrid Electric Vehicles”, NREL (forthcoming)
} 


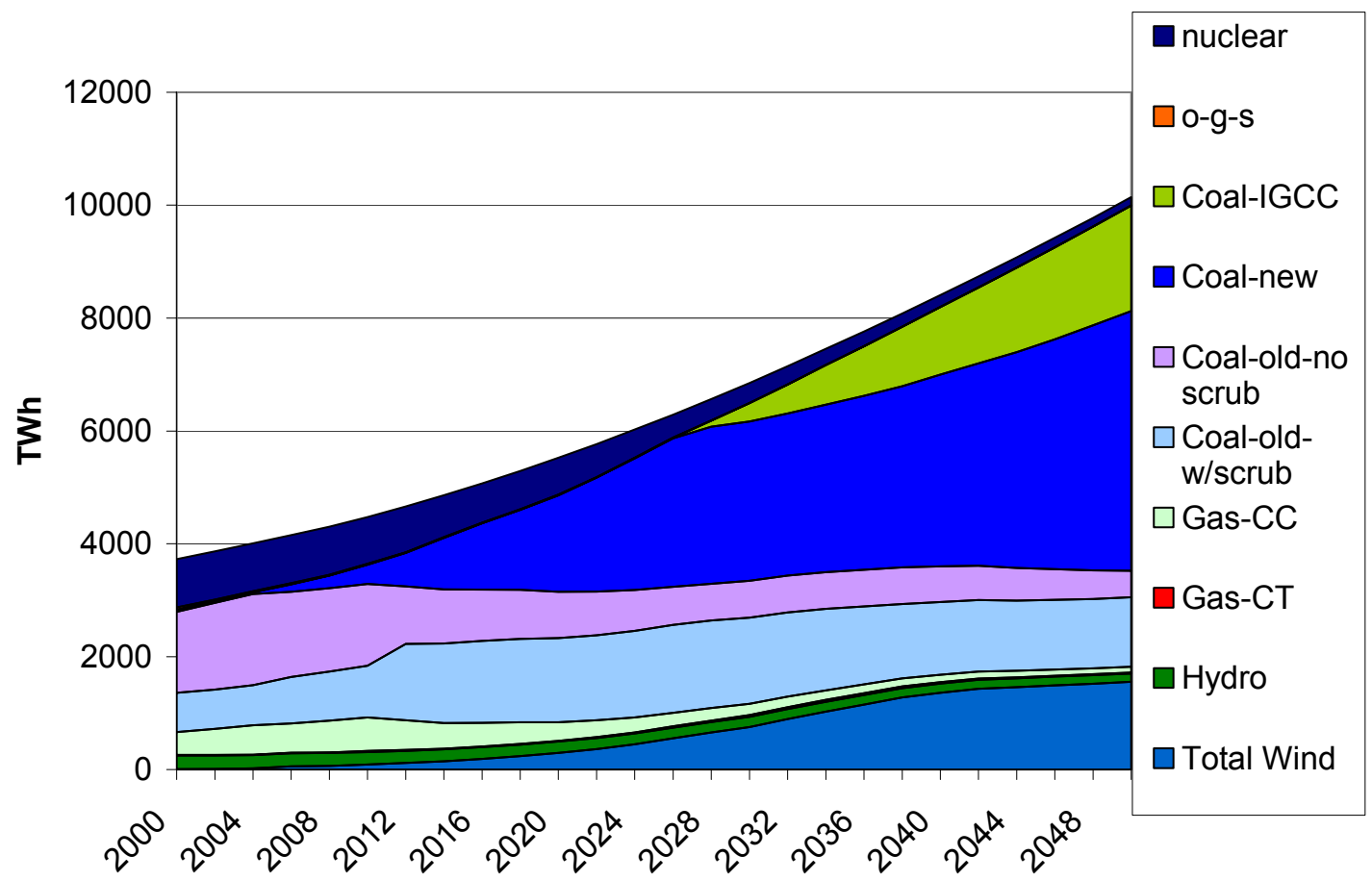

Figure 7: Electricity Generation in the WinDS PHEV-60 Case

The large amount of reserve capacity provided by PHEVs in the PHEV-60 case eliminates the need for much of the conventional capacity formerly required to stabilize the electric grid. This allows wind to compete more on a "cost of energy" basis. In other words, a nondispatchable $\mathrm{kWh}$ of energy from wind can compete more directly with a dispatchable $\mathrm{kWh}$ from conventional sources. Because a significant amount of wind generation is projected to be at or below the cost of conventional alternatives on a purely energy basis, the deployment of PHEVs results in vastly increased use of wind.

Figure 8 shows the change over time in generation from the base case to the PHEV-60 case. After a period in which both wind and coal increase due to the increased load of PHEVs, the reserve capacity offered by PHEVs allows wind to both replace coal that would have been otherwise built to meet normal load, as well as satisfy the increased electricity demand due to PHEVs. 


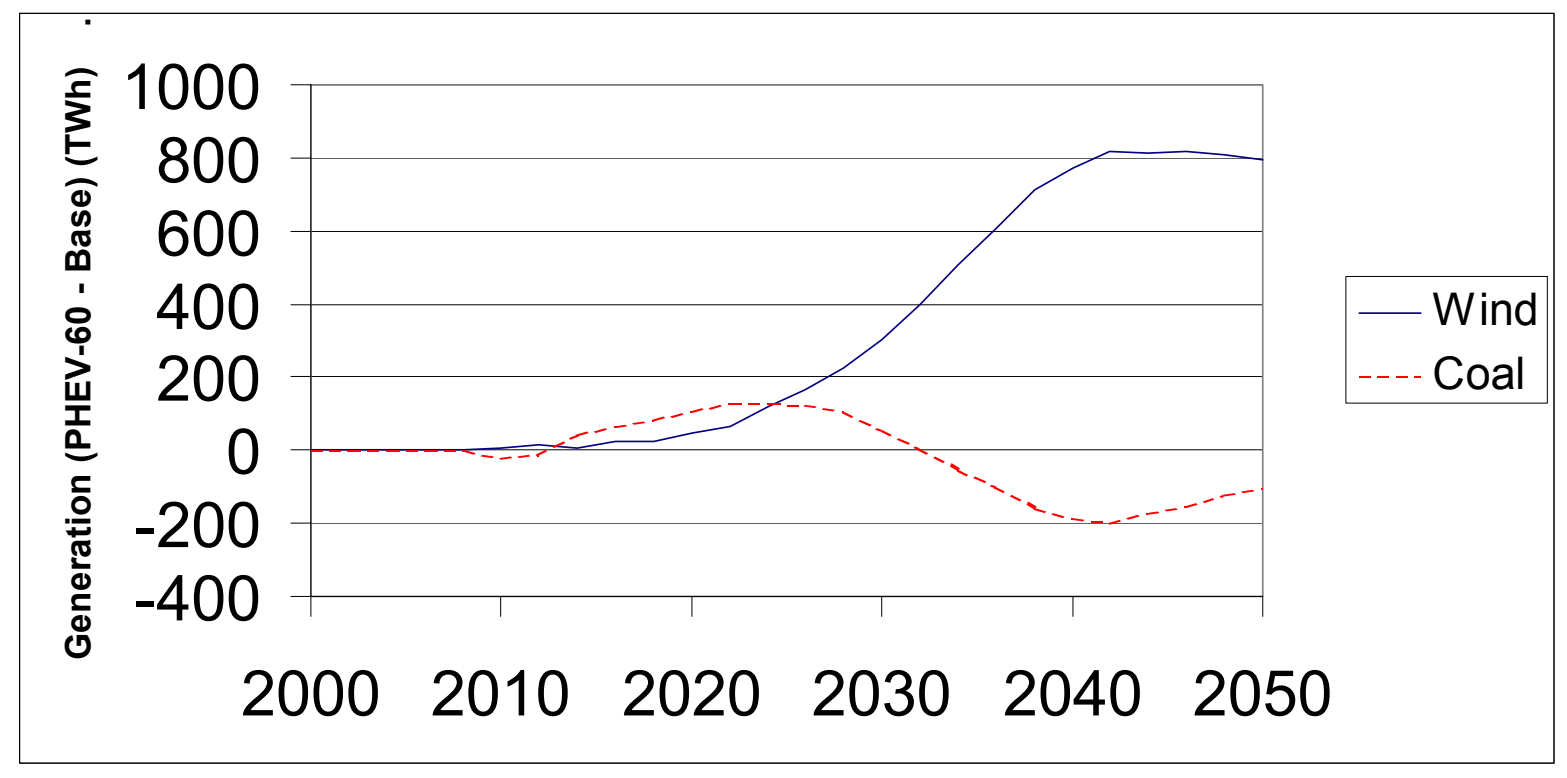

Figure 8: Comparison of Generation by Wind and Coal in the Base and PHEV-60 Cases

The possibility of wind effectively providing the entire electric demands of a PHEV-60 fleet is illustrated in Table 2. In this case, the additional annual PHEV load in 2050 is $690 \mathrm{TWh}$, while the additional wind generation created by the addition of PHEVs is 797 TWh. This means that the additional wind can meet the entire additional PHEV demand, with 107 TWh of wind generation "left over" to decrease the amount of coal generation needed for normal (non-PHEV) demand.

Table 2: Summary of 2050 WinDS/PHEV Results

\begin{tabular}{|l|c|c|c|}
\hline 2050 Projected Values & $\begin{array}{c}\text { Base Case (no } \\
\text { PHEVs) }\end{array}$ & PHEV-20 Case & PHEV-60 Case \\
\hline Wind Capacity (GW) & 208 & $\begin{array}{c}235 \\
(13 \% \text { increase })\end{array}$ & $\begin{array}{c}443 \\
(113 \% \text { increase })\end{array}$ \\
\hline Wind Generation (TWh/year) & 757 & $\begin{array}{c}853 \\
(13 \% \text { increase })\end{array}$ & $\begin{array}{c}1554 \\
(105 \% \text { increase })\end{array}$ \\
\hline Total Load (TWh/year) & 9392 & $\begin{array}{c}9808 \\
(4.4 \% \text { increase } \\
\text { due to PHEV } \\
\text { load) }\end{array}$ & $\begin{array}{c}10082 \\
(7.3 \% \text { increase } \\
\text { due to PHEV } \\
\text { load })\end{array}$ \\
\hline \% Of Electricity from Wind & 8.1 & 8.7 & 15.6 \\
\hline $\begin{array}{l}\text { Total Installed Generation } \\
\text { Capacity (GW) }\end{array}$ & 2161 & 2092 & 1972 \\
\hline $\begin{array}{l}\text { Generation from Coal } \\
\text { (TWh/year) }\end{array}$ & 8272 & $\begin{array}{c}8597 \\
(3.9 \% \text { increase })\end{array}$ & $\begin{array}{c}8169 \\
(1 \% \text { decrease })\end{array}$ \\
\hline $\begin{array}{l}\text { Electric Sector CO2 Emissions } \\
\text { (Million Tons CO2/year) }\end{array}$ & 7273 & $\begin{array}{c}7538 \\
(3.6 \% \text { increase })\end{array}$ & $\begin{array}{c}7220 \\
(1 \% \text { decrease })\end{array}$ \\
\hline
\end{tabular}

Not only do PHEVs increase the amount of cost-effective wind, they also reduce the need for peaking combustion turbines - which, by 2050 , amount to about $500 \mathrm{GW}$ in the base 
case and less than $90 \mathrm{GW}$ in the PHEV-60 case. ${ }^{20}$ Nonetheless, the total installed electric capacity is similar in all three cases. The additional wind enabled by PHEVs has a lower capacity factor than the fossil plants displaced, requiring more capacity per unit of generation. Hence, the reduction in combustion turbine capacity is offset by additional wind capacity.

The above discussion has emphasized the dramatic impacts of the PHEV-60 case in the electric sector. The PHEV impact in the electric sector under the PHEV-20 case is less impressive. The PHEV-20 electric energy requirements increase the total electric load $4.4 \%$ over the base case. This additional load is met by new generation from wind and other generators, primarily coal. Wind generation increases $13 \%$ over the base case, while coal generation increases by $4 \%$ (the $96 \mathrm{TWh} /$ year increase in wind generation is insufficient to meet the $416 \mathrm{TWh} /$ year increase in electric demand associated with PHEVs). The net effect is a $3.6 \%$ increase in carbon emissions from the electric sector (The next two sections will show, however, that total carbon emissions from both the combined electric and transportation sectors decrease)

It is important to keep in mind that many of the best wind sites used in the PHEV-60 case are still available in the PHEV-20 case, which further decreases carbon emissions in the electric sector. These wind sites could be developed if more storage were available through PHEVs or other storage technologies - or if the cost of wind improved relative to other generation options.

In both the PHEV-20 and the PHEV-60 cases, the ability of the PHEVs to provide reserve capacity to the grid was constrained by the energy available in their batteries. This constraint would be largely removed if it were possible to operate the IC engines of these vehicles while parked and connected to the grid. This possibility has significant safety and control issues associated with it. The authors examine its impact on the grid and the penetration of wind in Appendix 1.

\section{Impacts on the Transportation Sector}

The impact of PHEVs on gasoline use and mobile source emissions in 2050 depends partly on the assumed fleet characteristics in 2050 in the various cases. Table 3 provides estimates of the LDV gasoline consumption and $\mathrm{CO}_{2}$ emissions under two cases, where the fleet average for non-PHEVs is $22 \mathrm{mpg}$ and $35 \mathrm{mpg}$. In both cases, it is assumed that the average PHEV has an efficiency of $35 \mathrm{mpg}$ when operating in HEV mode.

\footnotetext{
${ }^{20}$ The impact on generation from CT's is minimal, since these generators, built primarily to meet reserve requirements, are idle most of the time
} 
Table 3: Summary of 2050 Results for LDV Fleet Gasoline Consumption and Emissions

\begin{tabular}{|l|c|c|c|}
\hline $\begin{array}{l}\text { 2050 Projected LDV Transportation } \\
\text { Sector }\end{array}$ & $\begin{array}{c}\text { Base Case } \\
\text { (no PHEVs) }\end{array}$ & $\begin{array}{c}\text { PHEV-20 } \\
\text { Case }\end{array}$ & $\begin{array}{c}\text { PHEV-60 } \\
\text { Case }\end{array}$ \\
\hline Gasoline Use (Billion gal/year) & & 148 & 127 \\
Conventional Fleet (22 mpg avg) & 226 & 107 & 85 \\
HEV Fleet (35 mpg avg) & 142 & 1486 & 1273 \\
\hline CO2 Emissions (Mil. Tons/year) & 2261 & 1066 & 853 \\
Conventional Fleet (22 mpg avg) & 1422 & \multicolumn{2}{|l}{} \\
HEV Fleet (35 mpg avg) & & & \\
\hline
\end{tabular}

Simple arithmetic shows that the assumption of a 50\% penetration of PHEV-20s by 2050, with $50 \%$ of their drive energy provided by electricity, results in at least a $25 \%(0.5 * 0.5)$ reduction in base oil consumption for the fleet of U.S. light-duty vehicles (see the "HEV Fleet" line under "Gasoline Use" in Table 3). As shown in Table 3, this $25 \%$ reduction in oil use would produce a proportional $25 \%$ reduction in carbon emissions from LDVs (see the "HEV Fleet" line under " $\mathrm{CO}_{2}$ Emissions" in Table 3). If the fleet is dominated by PHEV-60s (last column of Table 3), or the remaining vehicles are dominated by conventional low-efficiency vehicles (see "Conventional Fleet" lines in Table 3), the reduction in petroleum use could be even greater.

\section{Combined Impacts}

Table 4 provides a summary of the combined impacts of PHEVs in the electric and LDV sectors.

Table 4: Summary of 2050 Results for LDV Fleet Gasoline Consumption and Emissions

\begin{tabular}{|l|c|c|c|}
\hline $\begin{array}{l}\text { 2050 Projected CO2 Emissions } \\
\text { from the combined electric/LDV } \\
\text { sector (Million Tons/year) }\end{array}$ & $\begin{array}{c}\text { Base Case } \\
\text { (no PHEVs) }\end{array}$ & $\begin{array}{c}\text { PHEV-20 } \\
\text { Case }\end{array}$ & $\begin{array}{c}\text { PHEV-60 } \\
\text { Case }\end{array}$ \\
\hline Conventional Fleet (22 mpg avg.) & 9534 & 9024 & 8493 \\
\hline HEV Fleet (35 mpg avg.) & 8695 & 8604 & 8073 \\
\hline
\end{tabular}

The somewhat-limited reduction in overall carbon emissions results partly from the fact that half of the vehicle fleet is still $100 \%$ petroleum-fueled. An alternative viewpoint is to examine the net change in emissions associated with the PHEV fleet. In the PHEV-60 case, the fleet results in a carbon reduction of 622 or 1,041 million tons/year of $\mathrm{CO}_{2}$, depending on the base fuel economy. This can be compared to the emissions of $50 \%$ of the vehicle fleet (711 or 1,131 million tons/year). The net reduction in carbon emissions due to the introduction of PHEV-60s is nearly equal to the emissions of these vehicles in the base case. In other words, all the electricity from PHEV-60s is derived from carbonfree wind enabled by the vehicles; and the additional carbon reduction in the electric sector of 53 million tons/year due to the introduction of PHEVs is a large fraction of the PHEV fleets' 142 million tons of IC engine emissions. As a result, the PHEV-60 fleet is nearly carbon neutral. 


\section{Conclusions}

The results in this paper are limited by the fact that the authors have not considered the economics of PHEVs. In addition, they have examined only two cases (and the additional IC engine-on case in Appendix 1). These cases represent fixed points with many assumptions regarding fleet size, vehicle efficiency, driving patterns, and plug-in rates.

Nonetheless, these cases do allow several provisional conclusions to be drawn. First, it does appear that PHEVs could be a significant enabling factor for increased penetration of wind energy. However, this will likely require greater storage capacity than the PHEV-20 case presented in this report. Increasing wind penetration through the use of PHEVs would require any combination of the following: increasing the size of the PHEV fleet, increasing the PHEV plug-in-rate, increasing the PHEV battery size, or allowing the IC engine to run to provide greater capacity. The more aggressive PHEV-60 case resulted in more than doubling installed wind capacity, as well as decreasing electricsector carbon emissions, even considering the increased electric load resulting from the replacement of $40 \%$ of the nation's LDV gasoline use with electricity.

It should also be noted that the potentially conservative battery size in the PHEV-20 case may have a significant impact on these provisional results. The $5.9 \mathrm{kWh}$ battery size used in this report is based on a electric drive efficiency of $3.4 \mathrm{miles} / \mathrm{kWh}$, which assumes that the average new vehicle sold in the United States in the future will be significantly smaller (and/or lighter) than the current average new vehicle, which is heavily influenced by low-efficiency SUVs and light-duty trucks. If the average vehicle sold in the United States continues to be relatively large in size, then the average electricdrive efficiency of PHEVs will be lower, requiring larger batteries. These larger batteries will result in more per-vehicle reserve capacity, which could increase the amount of wind enabled by a PHEV fleet.

PHEVs present a significant opportunity to directly address two of the most prominent energy issues faced by the United States today-oil imports/energy security and climate change. In addition, the reductions in oil use possible through the introduction of PHEVs worldwide could reduce pressures on international oil supplies, decreasing the price of oil.

\section{Future Work}

This report presents a scoping study that estimates the potential benefit of PHEVs by enabling increased wind generation in the electric sector. However, it's still necessary to estimate the costs of PHEVs and their competitive position in the marketplace. This task is complicated by the fact that PHEVs have value both as a means of transportation and as a means of providing reserve capacity to the electric sector. Future efforts will examine these costs and the full set of PHEV benefits, analytically estimating the penetration of PHEVs into the market (as opposed to the simple assumptions on penetration made for this analysis). This will require a better representation of driving 
profiles for LDVs, implications of those driving profiles for PHEV charging profiles, estimation of regulation reserve benefits provided by PHEVs, and the marriage of a vehicle-choice model with our WinDS model. 


\section{Appendix 1: Effects of Increasing PHEV Reserve Capacity via "Engine-On" Capability.}

The increase in wind penetration in the PHEV-60 case depends on the capacity offered by a relatively large battery. Given the relatively high cost of batteries and typical driving patterns, a PHEV-20 may be more suited to most consumers. Given the modest improvements in wind penetration in the PHEV-20 case-and the PHEV-20's potentially more likely market penetration - the authors decided to investigate an alternative PHEV20 scenario that allows the vehicle's IC engine to run. Allowing the IC engine to run substantially increases the per-vehicle planning capacity. Because most peaking generators are run for a very small number of hours per year, it may be acceptable for some fraction of vehicles to run their engines on rare occasions to provide firm capacity. However, the fraction of vehicles capable of running the IC engine would be limited by a number of issues such as safety, security, owner concerns, etc. For example, ventilation in open parking garages may be inadequate, and costly safety interlocks would be required to eliminate dangers associated with vehicle operation in closed garages. In addition, the cooling systems of vehicles may have to be upgraded to reject the heat that would be produced by a stationary vehicle generating more than a few $\mathrm{kW}$, especially because the planning capacity of the vehicles in the electric system most likely would be rated at their capacity on hot summer days.

Allowing a utility to remotely start and control privately owned vehicles raises many concerns that are not trivial nor easily dismissed. However, these issues may not be insurmountable, at least for some fraction of the PHEV fleet (perhaps including large corporate fleets and government-owned vehicles).

Actual operation of the engines of these PHEVs while parked will be a relatively rare occurrence, because much of the use of operating and planning reserves is for extreme scenarios-such as a generator failure during peak demand. Furthermore, since capacity reserves typically provide a very small amount of energy, the overall fuel use and resulting pollution (even though greater with engine start-up than is indicated by averageEPA-cycle estimates) could be relatively small. (These emissions would have to be compared to alternative peaking generation units that include older less efficient thermal plants, IC engines or simple-cycle CTs that may have relatively high emission rates.)

To consider this possibility, the authors created a PHEV-20 "engine run" case, where they allowed up to $30 \%$ of all PHEVs to run their engines while parked. In this case, the planning capacity credit was $1.8 \mathrm{~kW} /$ vehicle, and the operating capacity was 3.9 $\mathrm{kW} / \mathrm{vehicle.}$

The result of the WinDS run in this case was a total wind installation of $483 \mathrm{GW}$ of wind, about 10\% more than the PHEV-60 case. This demonstrates that smaller PHEVs may still enable large increases in wind energy, if the engine is allowed to run during extreme events. The authors believe the actual amount of engine run to be relatively small (much less than 100 hours per year), but further work will be needed to provide a better estimate of both the numbers of hours per year and the number of engine-on events that might be required for each vehicle. 


\section{Appendix 2: Summary of Data Used in WinDS}

NOTE: A more comprehensive data set and documentation is available in

"Documentation of WinDS Base Case Data" available at http://www.nrel.gov/analysis/winds/pdfs/winds data.pdf

\section{1) Introduction}

The Wind Deployment System (WinDS) model is a computer model that optimizes the regional expansion of electric generation and transmission capacity in the continental United States over the next 50 years. WinDS competes many different generation types to design a "least-cost" electric power system under a number of technical, reliability, and environmental constraints. Detailed documentation of the WinDS model formulation is available at http://www.nrel.gov/analysis/winds/.

This document summarizes the key data inputs to the Base Case of the WinDS model. The Base Case was developed simply as a point of departure for other analyses to be conducted using the WinDS model. It does not represent a forecast of the future, but rather is a consensus scenario whose inputs depend strongly on others' results and forecasts. For example, WinDS derives many of its inputs from the EIA's Annual Energy Outlook (EIA 2005) — particularly its conventional technology cost and performance parameters, its current and future fossil fuel prices, and its electric-sector loads.

The following sections present the parameters and input values used for the WinDS Base Case. Unless specifically stated otherwise, all cost data are expressed in year 2004 dollars.

\section{2) Financials}

WinDS optimizes the electric power system "build," based on the projected life-cycle costs, including capital costs and cumulative discounted operating costs over a fixed evaluation period. The "overnight" capital costs are adjusted to reflect the actual total cost of construction, including tax effects, interest during construction, and financing mechanisms. Table A2.1 provides a summary of the financial values used to produce the net capital and operating costs.

Table A2.1: Base Case Financial Assumptions

\begin{tabular}{|l|l|l|}
\hline Name & Value & Notes \& Source \\
\hline Inflation Rate & $3 \%$ & Based on recent historical inflation rates \\
\hline Real Discount Rate & $8.5 \%$ & $\begin{array}{l}\text { Equivalent to weighted cost of capital. Based on EIA } \\
\text { assumptions (U.S. DOE 2005b) }\end{array}$ \\
\hline
\end{tabular}




\begin{tabular}{|l|l|l|}
\hline Debt/Equity Ratio & 0 & $\begin{array}{l}\text { Consistent with the use of a weighted cost of capital for the } \\
\text { real discount rate }\end{array}$ \\
\hline Real interest rate & 0 & $\begin{array}{l}\text { Consistent with the use of a weighted cost of capital for the } \\
\text { real discount rate }\end{array}$ \\
\hline $\begin{array}{l}\text { Marginal Income } \\
\text { Tax Rate }\end{array}$ & $40 \%$ & Combined Federal/State Corporate Income Tax Rate \\
\hline Evaluation Period & 20 Years & Base Case Assumption \\
\hline $\begin{array}{l}\text { Depreciation } \\
\text { Schedule } \\
\begin{array}{l}\text { Conventionals } \\
\text { Wind }\end{array}\end{array}$ & $\begin{array}{l}15 \text { Year } \\
5 \text { Year }\end{array}$ & $\begin{array}{l}\text { MACRS } \\
\text { MACRS }\end{array}$ \\
\hline $\begin{array}{l}\text { Nominal Interest } \\
\text { rate during } \\
\text { construction }\end{array}$ & $10 \%$ & Base Case Assumption \\
\hline Dollar year & 2004 & All costs are expressed in year 2004 dollars \\
\hline
\end{tabular}

\section{3) Power System Characteristics}

\subsection{Electric System Loads}

Loads are defined by region and by time. WinDS meets both the energy requirement and the power requirement for each of 136 Power Control Area (PCA) regions. Energy is met for each PCA in each of 16 time slices within each year modeled by WinDS. Time slices are defined in Table A2.2.

Table A2.2: WinDs Demand Time-Slice Definitions

\begin{tabular}{|c|c|c|l|}
\hline $\begin{array}{c}\text { Slice } \\
\text { Name }\end{array}$ & $\begin{array}{c}\text { Number } \\
\text { of Hours } \\
\text { Per Year }\end{array}$ & Season & \multicolumn{1}{|c|}{ Time Period } \\
\hline H1 & $\mathbf{1 1 5 2}$ & Summer & Weekends plus 11PM-6AM weekdays \\
\hline H2 & $\mathbf{4 6 2}$ & Summer & Weekdays 7AM-1PM \\
\hline H3 & $\mathbf{2 6 4}$ & Summer & Weekdays 2PM-5PM \\
\hline H4 & $\mathbf{3 3 0}$ & Summer & Weekdays 6PM-10PM \\
\hline H5 & $\mathbf{7 9 2}$ & Fall & Weekends plus 11PM-6AM weekdays \\
\hline H6 & $\mathbf{3 1 5}$ & Fall & Weekdays 7AM-1PM \\
\hline H7 & $\mathbf{1 8 0}$ & Fall & Weekdays 2PM-5PM \\
\hline H8 & $\mathbf{2 2 5}$ & Fall & Weekdays 6PM-10PM \\
\hline H9 & $\mathbf{1 4 9 6}$ & Winter & Weekends plus 11PM-6AM weekdays \\
\hline H10 & $\mathbf{5 9 5}$ & Winter & Weekdays 7AM-1PM \\
\hline H11 & $\mathbf{3 4 0}$ & Winter & Weekdays 2PM-5PM \\
\hline H12 & $\mathbf{4 2 5}$ & Winter & Weekdays 6PM-10PM \\
\hline H13 & $\mathbf{1 1 4 4}$ & Spring & Weekends plus 11PM-6AM weekdays \\
\hline H14 & $\mathbf{4 5 5}$ & Spring & Weekdays 7AM-1PM \\
\hline H15 & $\mathbf{2 6 0}$ & Spring & Weekdays 2PM-5PM \\
\hline H16 & $\mathbf{3 2 5}$ & Spring & Weekdays 6PM-10PM \\
\hline
\end{tabular}

The seasons in Table A2.2 are defined as:

Summer: June, July, August

Fall: September, October

Winter: November, December, January, February

Spring: March, April, May 
The electric load in 2000 for each PCA and time slice is derived from a RDI/Platts database (http://www.platts.com/Analytic\%20Solutions/BaseCase/). Figure A2.1 is the WinDS load-duration curve for the entire United States for the base year, illustrating the 16 load time slices. As a reference, the actual U.S. coincident load-duration curve is illustrated as well (also derived from the Platts database). This aggregated data for the United States shown in Figure A2.1 is not used directly in WinDS, as the energy requirement is met in each PCA. However, this curve does give a general idea of the WinDS energy requirement. It should be noted that the load-duration curve does not include the "super peak," which occurs in most systems for a few hours per year.

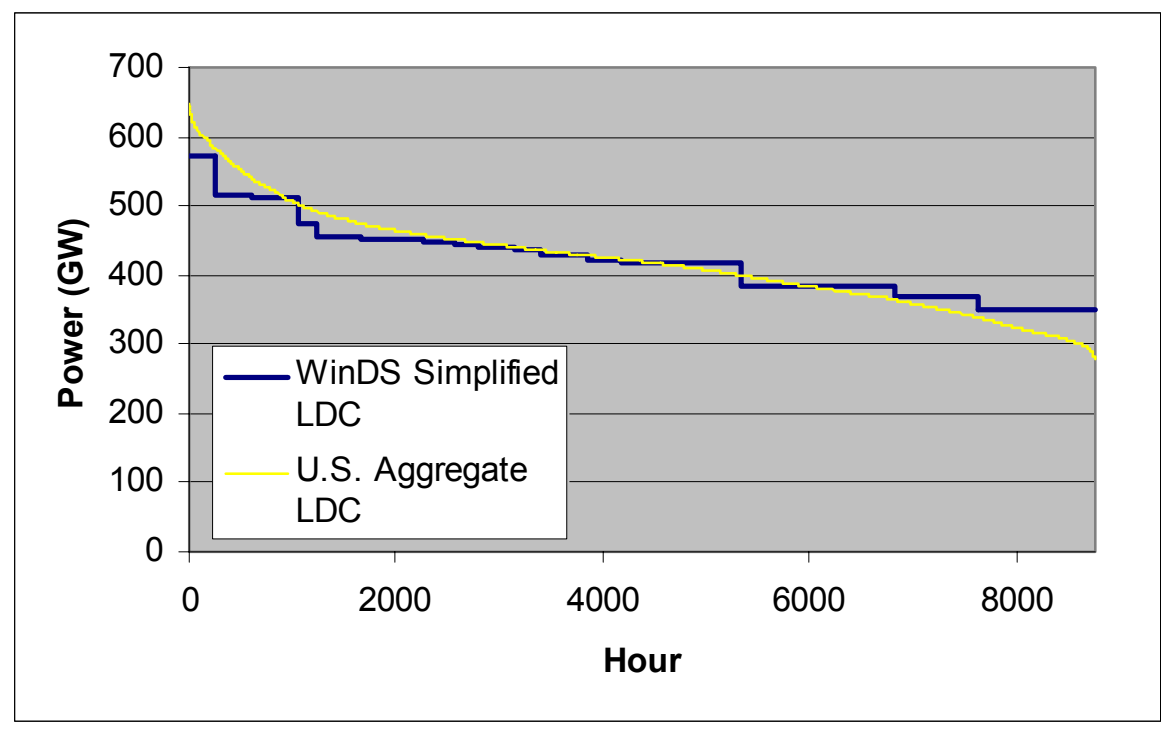

Figure A2.1: National Load-Duration Curve for Base Year in WinDS

\subsection{Growth Rate and Capacity Requirements}

Load growth is defined at the NERC Region level. It is assumed that the load in all PCAs within each NERC region grows at the same rate. Table A2.3 provides the annual growth rates for each NERC region. The load growth rates are assumed to be uniform in each PCA, based on NERC Region.

WinDS assumes that the growth rate in each time slice is constant; i.e. the load shape remains the same for all regions.

There are two basic categories of capacity requirements in WinDS:

1) Capacity for Peak Energy -This is the amount of reliable capacity actually delivering power during the peak time slice shown in Table A2.3. This total capacity includes all plant types (including wind) and considers the forced outage rate for each type.

2) Capacity for Peak Demand and Peak Reserve - This is the total system capacity, equal to the peak load plus an additional fraction, determined by the 
reserve margin. The peak load is somewhat greater than the peak energy time slice, and represents the "super peak," which occurs for a few hours per year. The peak reserve represents additional capacity to cover contingencies caused by generator or transmission system failure or unexpected peak demand. The peak demand and reserve are combined into a single capacity requirement in WinDS. The capacity constructed to meet the peak reserve margin in WinDS is not required to actually deliver energy. The small amount of energy that is typically delivered by this "super peak" capacity in real systems is delivered in the form of the peak time-slice generation in WinDS.

Table A2.3 provides the growth rates and reserve-margin requirements for each NERC region.

Table A2.3: Growth Rates and Required Reserve Margins

\begin{tabular}{|c|c|c|c|}
\hline NERC Region & Abbreviation & $\begin{array}{c}\text { Annual Load } \\
\text { Growth }\end{array}$ & $\begin{array}{c}\text { Required } \\
\text { Reserve Margin }\end{array}$ \\
\hline 1 & ECAR & 1.019 & 0.12 \\
\hline 2 & ERCOT & 1.021 & 0.15 \\
\hline 3 & MAAC & 1.016 & 0.15 \\
\hline 4 & MAIN & 1.018 & 0.12 \\
\hline 5 & MAPP & 1.017 & 0.12 \\
\hline 6 & NY & 1.017 & 0.18 \\
\hline 7 & NE & 1.017 & 0.15 \\
\hline 8 & FL & 1.019 & 0.15 \\
\hline 9 & STV/SERC & 1.017 & 0.13 \\
\hline 10 & SPP & 1.012 & 0.12 \\
\hline 11 & NWP & 1.025 & 0.08 \\
\hline 12 & RA & 1.026 & 0.14 \\
\hline 13 & CNV & 1.021 & 0.13 \\
\hline
\end{tabular}

Notes:

1) NERC Regions defined by http://www.nerc.com/regional/

2) Reserve margin is ramped from initial value in 2000 to the 2010 requirement and maintained thereafter. Source: Energy Observer Issue No. 2, July 2004, PA Consulting Group

3) Reserve margin may be met by any generator type, or by interruptible load.

4) Growth Rate from: U.S. DOE. 2005b (Tables 60 through 72 "Total Net Energy For Load")

Figure A2.2 illustrates the capacity requirements in 2000 and 2050. As noted previously, the peak reserve and peak demand are combined as a single constraint in the WinDS model. 


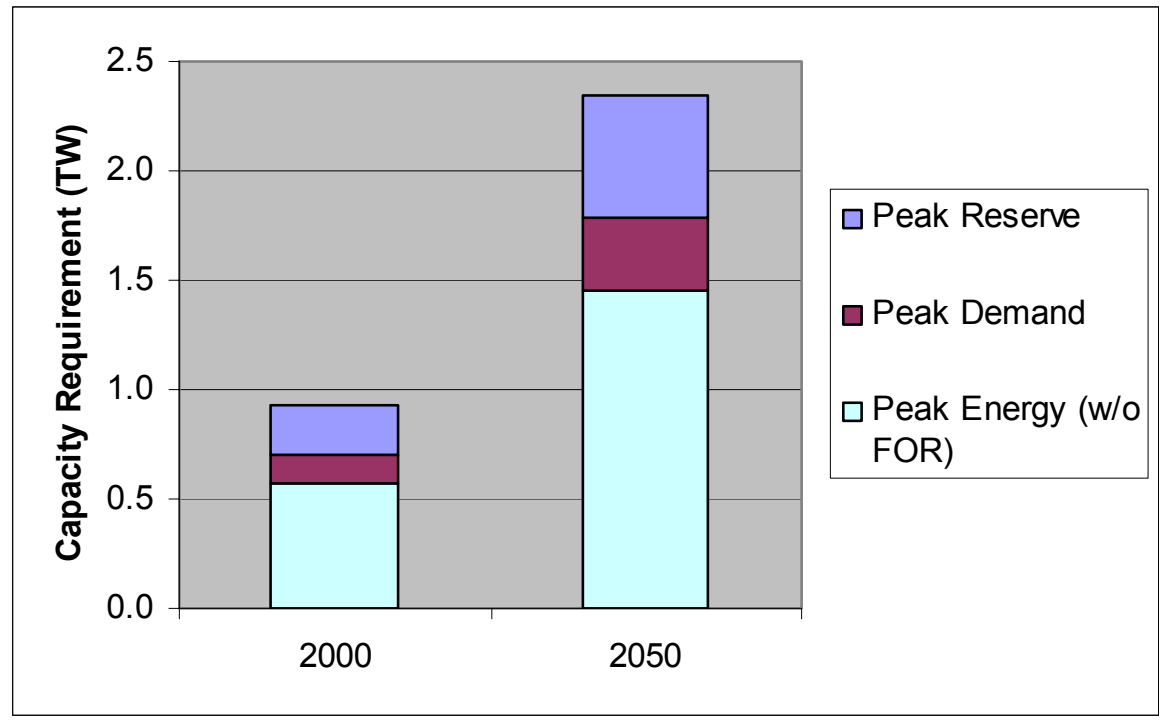

Figure A2.2: National Capacity Requirement in WinDS

\section{4) Wind}

\subsection{Wind Resource Definition}

Wind power classes are defined as follows:

Table A2.4. Classes of Wind Power Density

\begin{tabular}{|c|c|c|}
\hline $\begin{array}{c}\text { Wind } \\
\text { Power } \\
\text { Class }\end{array}$ & $\begin{array}{c}\text { Wind Power } \\
\text { Density, W/m }\end{array}$ & $\begin{array}{c}\text { Speed } \\
\mathbf{m} / \mathbf{s} \text { (mph) }\end{array}$ \\
\hline 3 & $300-400$ & $6.4-7.0$ \\
\hline 4 & $400-500$ & $7.0-7.5$ \\
\hline 5 & $500-600$ & $7.5-8.0$ \\
\hline 6 & $600-800$ & $8.0-8.8$ \\
\hline 7 & $>800$ & $>8.8$ \\
\hline
\end{tabular}

Note: Wind speed measured at 50 meters above ground level Source: Elliott and M.N. Schwartz 1993

The wind power density and speed are not used explicitly in WinDS. The different classes of wind power are distinguished in WinDS through the resource levels, capacity factors, turbine costs, etc., all of which are discussed in the following paragraphs.

\subsection{Resources}

The wind resource dataset for the WinDS model is based on a "supply curve" for onshore, shallow offshore, and deep offshore. Each is expressed in the following format: 


\begin{tabular}{|c|c|c|c|c|c|}
\hline Wind Region & $\begin{array}{c}\text { Class 3 } \\
\text { Resource } \\
\text { (MW) }\end{array}$ & $\begin{array}{c}\text { Class 4 } \\
\text { Resource } \\
\text { (MW) }\end{array}$ & $\begin{array}{c}\text { Class 5 } \\
\text { Resource } \\
\text { (MW) }\end{array}$ & $\begin{array}{c}\text { Class 6 } \\
\text { Resource } \\
\text { (MW) }\end{array}$ & $\begin{array}{c}\text { Class 7 } \\
\text { Resource } \\
\text { (MW) }\end{array}$ \\
\hline 1 & 926.5 & 286.4 & 82.3 & 41.5 & 18.8 \\
\hline 2 & 214.9 & 69 & 43.7 & 43.7 & 16.7 \\
\hline 3 & 467.1 & 248.3 & 127.7 & 120.3 & 66.9 \\
\hline 4 & 3265.6 & 2100.9 & 501.1 & 86.8 & 6.1 \\
\hline
\end{tabular}

This regional wind resource dataset is generated by multiplying the total available area of a particular wind resource by an assumed wind farm density of $5 \mathrm{MW} / \mathrm{km}^{2}$.

(http://www.nrel.gov/wind/uppermidwestanalysis.html).

The amount of land available for each class is based on a dataset for each of the 358 wind regions for onshore, shallow offshore, and deep offshore.

\subsection{Basic Wind Cost and Performance}

The following tables provide the projected cost and performance for land-based (onshore) and offshore (shallow and deep) wind turbines. The onshore values were derived from data obtained from personal communication between the authors and Joseph Cohen at Princeton Energy Resources International (2003). Cohen's data was manipulated to divide the cost/performance improvements into that due to industry learning-by-doing and that due to R\&D. The improvements shown in Table A2.5 represent that due to only R\&D. The learning-by-doing improvements are calculated endogenously within WinDS using an $8 \%$ learning rate (McDonald, 2001), based on both U.S. and world production estimates.

Table A2.5: Onshore Turbines (values constant after 2020)

\begin{tabular}{|c|c|c|c|c|c|}
\hline $\begin{array}{l}\text { Resource } \\
\text { Class }\end{array}$ & Install Year & $\begin{array}{c}\text { Capacity } \\
\text { Factor }\end{array}$ & $\begin{array}{l}\text { Capital cost } \\
(\$ / \mathrm{kW})^{*}\end{array}$ & $\begin{array}{c}\text { Fixed O\&M } \\
\text { (\$/kW-yr) }\end{array}$ & $\begin{array}{c}\text { Variable } \\
\text { O\&M } \\
\text { (\$/MWh) }\end{array}$ \\
\hline 3 & 2000 & 0.2 & 942.60 & 7.54 & 4.71 \\
\hline 3 & 2005 & 0.25 & 929.24 & 7.54 & 3.77 \\
\hline 3 & 2010 & 0.275 & 922.57 & 7.54 & 3.71 \\
\hline 3 & 2020 & 0.3 & 915.89 & 7.54 & 3.64 \\
\hline 4 & 2000 & 0.251 & 942.60 & 7.54 & 4.71 \\
\hline 4 & 2005 & 0.2885 & 915.89 & 7.54 & 3.77 \\
\hline 4 & 2010 & 0.349 & 914.32 & 7.54 & 3.71 \\
\hline 4 & 2020 & 0.361 & 898.61 & 7.54 & 3.64 \\
\hline 5 & 2000 & 0.3225 & 942.60 & 7.54 & 4.71 \\
\hline 5 & 2005 & 0.3535 & 897.82 & 7.54 & 3.77 \\
\hline 5 & 2010 & 0.397 & 897.04 & 7.54 & 3.71 \\
\hline 5 & 2020 & 0.4135 & 881.33 & 7.54 & 3.64 \\
\hline 6 & 2000 & 0.394 & 942.60 & 7.54 & 4.71 \\
\hline 6 & 2005 & 0.4185 & 879.76 & 7.54 & 3.77 \\
\hline 6 & 2010 & 0.445 & 879.76 & 7.54 & 3.71 \\
\hline 6 & 2020 & 0.466 & 864.05 & 7.54 & 3.64 \\
\hline
\end{tabular}




\begin{tabular}{|l|c|c|c|c|c|}
\hline 7 & 2000 & 0.414 & 942.60 & 7.54 & 4.71 \\
7 & 2005 & 0.4385 & 879.76 & 7.54 & 3.77 \\
7 & 2010 & 0.465 & 879.76 & 7.54 & 3.71 \\
7 & 2020 & 0.486 & 864.05 & 7.54 & 3.64 \\
\hline
\end{tabular}

${ }^{*}$ Overnight capital cost

Table A2.6: Shallow Offshore Turbines (values constant after 2025)

\begin{tabular}{|c|c|c|c|c|c|}
\hline $\begin{array}{c}\text { Resource } \\
\text { Class }\end{array}$ & $\begin{array}{c}\text { Install } \\
\text { Year }\end{array}$ & $\begin{array}{c}\text { Capacity } \\
\text { Factor }\end{array}$ & $\begin{array}{c}\text { Capital cost } \\
\mathbf{( \$ / k W )}\end{array}$ & $\begin{array}{c}\text { Fixed O\&M } \\
\text { (\$/kW-yr) }\end{array}$ & $\begin{array}{c}\text { Variable O\&M } \\
\mathbf{( \$ / M W h )}\end{array}$ \\
\hline 3 & 2000 & 0.33 & 1194.00 & 10.00 & 15.00 \\
3 & 2005 & 0.33 & 1194.00 & 10.00 & 15.00 \\
3 & 2010 & 0.345 & 1143.83 & 10.00 & 14.13 \\
3 & 2020 & 0.35 & 1073.67 & 10.00 & 13.07 \\
3 & 2025 & 0.35 & 1064.33 & 10.00 & 12.77 \\
\hline 4 & 2000 & 0.33 & 1194.00 & 10.00 & 15.00 \\
4 & 2005 & 0.33 & 1194.00 & 10.00 & 15.00 \\
4 & 2010 & 0.345 & 1143.83 & 10.00 & 14.13 \\
4 & 2020 & 0.35 & 1073.67 & 10.00 & 13.07 \\
4 & 2025 & 0.35 & 1064.33 & 10.00 & 12.77 \\
\hline 5 & 2000 & 0.37 & 1194.00 & 10.00 & 15.00 \\
5 & 2005 & 0.37 & 1194.00 & 10.00 & 15.00 \\
5 & 2010 & 0.365 & 1143.83 & 10.00 & 14.13 \\
5 & 2020 & 0.395 & 1073.67 & 10.00 & 13.07 \\
5 & 2025 & 0.395 & 1064.33 & 10.00 & 12.77 \\
\hline 6 & 2000 & 0.42 & 1194.00 & 10.00 & 15.00 \\
6 & 2005 & 0.42 & 1194.00 & 10.00 & 15.00 \\
6 & 2010 & 0.4375 & 1143.83 & 10.00 & 14.13 \\
6 & 2020 & 0.445 & 1073.67 & 10.00 & 13.07 \\
6 & 2025 & 0.445 & 1064.33 & 10.00 & 12.77 \\
\hline 7 & 2000 & 0.44 & 1194.00 & 10.00 & 15.00 \\
7 & 2005 & 0.44 & 1194.00 & 10.00 & 15.00 \\
7 & 2010 & 0.4575 & 1143.83 & 10.00 & 14.13 \\
7 & 2020 & 0.465 & 1073.67 & 10.00 & 13.07 \\
7 & 2025 & 0.465 & 1064.33 & 10.00 & 12.77 \\
\hline
\end{tabular}

Table A2.7: Deep Offshore (cost and performance constant after 2025)

\begin{tabular}{|c|c|c|c|c|c|}
\hline $\begin{array}{c}\text { Resource } \\
\text { Class }\end{array}$ & Install Year & $\begin{array}{c}\text { Capacity } \\
\text { Factor }\end{array}$ & $\begin{array}{c}\text { Capital cost } \\
\mathbf{( \$ / k W )}\end{array}$ & $\begin{array}{c}\text { Fixed O\&M } \\
\mathbf{( \$ / k W - y r )}\end{array}$ & $\begin{array}{c}\text { Variable O\&M } \\
\mathbf{( \$ / M W h )}\end{array}$ \\
\hline 3 & 2000 & 0.33 & 2004.00 & 10.00 & 18.00 \\
3 & 2005 & 0.33 & 2004.00 & 10.00 & 18.00 \\
3 & 2010 & 0.345 & 1887.50 & 10.00 & 16.57 \\
3 & 2020 & 0.35 & 1735.67 & 10.00 & 15.40 \\
3 & 2025 & 0.35 & 1696.67 & 10.00 & 15.30 \\
\hline 4 & 2000 & 0.33 & 2004.00 & 10.00 & 18.00 \\
4 & 2005 & 0.33 & 2004.00 & 10.00 & 18.00 \\
4 & 2010 & 0.345 & 1887.50 & 10.00 & 16.57 \\
4 & 2020 & 0.35 & 1735.67 & 10.00 & 15.40
\end{tabular}




\begin{tabular}{|l|c|c|c|c|c|}
4 & 2025 & 0.35 & 1696.67 & 10.00 & 15.30 \\
\hline 5 & 2000 & 0.37 & 2004.00 & 10.00 & 18.00 \\
5 & 2005 & 0.37 & 2004.00 & 10.00 & 18.00 \\
5 & 2010 & 0.365 & 1887.50 & 10.00 & 16.57 \\
5 & 2020 & 0.395 & 1735.67 & 10.00 & 15.40 \\
5 & 2025 & 0.395 & 1696.67 & 10.00 & 15.30 \\
\hline 6 & 2000 & 0.42 & 2004.00 & 10.00 & 18.00 \\
6 & 2005 & 0.42 & 2004.00 & 10.00 & 18.00 \\
6 & 2010 & 0.4375 & 1887.50 & 10.00 & 16.57 \\
6 & 2020 & 0.445 & 1735.67 & 10.00 & 15.40 \\
6 & 2025 & 0.445 & 1696.67 & 10.00 & 15.30 \\
\hline 7 & 2000 & 0.44 & 2004.00 & 10.00 & 18.00 \\
7 & 2005 & 0.44 & 2004.00 & 10.00 & 18.00 \\
7 & 2010 & 0.4575 & 1887.50 & 10.00 & 16.57 \\
7 & 2020 & 0.465 & 1735.67 & 10.00 & 15.40 \\
7 & 2025 & 0.465 & 1696.67 & 10.00 & 15.30 \\
\hline
\end{tabular}

\section{5) Conventional Generation}

\subsection{Generator Types}

Available generator types that may be built are based on the most likely types, as determined by the DOE Energy Information Administration (U.S. DOE 2005c).

Table A2.8: Conventional (Non-Wind) Generation Types Considered by WinDS

\begin{tabular}{|l|c|l|}
\hline Generator Type & $\begin{array}{l}\text { Existing } \\
\text { Capacity? }\end{array}$ & May Be Built New In WinDS? \\
\hline $\begin{array}{l}\text { Conventional pulverized coal steam plant } \\
\text { (No SO2 Scrubber) }\end{array}$ & Y & $\begin{array}{l}\text { No - Scrubbers may be added to meet } \\
\text { SO2 constraints. Existing plants may } \\
\text { also switch to low-sulfur coal }\end{array}$ \\
\hline $\begin{array}{l}\text { Conventional pulverized coal steam } \\
\text { plants (With SO2 Scrubber) }\end{array}$ & No \\
\hline $\begin{array}{l}\text { Advanced supercritical coal steam plant } \\
\text { (With SO2 and NOx controls) }\end{array}$ & Y & Y \\
\hline $\begin{array}{l}\text { Integrated Coal Gasification Combined } \\
\text { Cycle (IGCC) }\end{array}$ & Y & Y - sequestration may be added \\
\hline Oil/Gas Steam Turbine (OGS) & Y & $\begin{array}{l}\text { N-Assumes CT or CCGT will be built } \\
\text { instead }\end{array}$ \\
\hline Combined Cycle Gas Turbine & Y - sequestration may be added \\
\hline Gas Combustion Turbine & Y & Y \\
\hline Fuel Cell & None & $\begin{array}{l}\text { Not in base case - Generic Fuel Cell } \\
\text { with H2 fuel is an optional technology }\end{array}$ \\
\hline Nuclear & Y & Y \\
\hline $\begin{array}{l}\text { Conventional Hydropower - Hydraulic } \\
\text { Turbine }\end{array}$ & Y & No - small hydro to be added \\
\hline Municipal Solid Waste / Landfill Gas & Y & No - to be added \\
\hline Biomass (as thermal steam generation) & Y & $\begin{array}{l}\text { No - to be added in the form of co- } \\
\text { firing, thermal steam, and/or } \\
\text { gasification }\end{array}$ \\
\hline
\end{tabular}


5.2 Cost and Basic Performance (capital cost, fixed O\&M, variable O\&M, heat rate)

Values for capital cost, heat rate (efficiency), fixed O\&M, and variable O\&M for conventional technologies are provided in Table A2.9.

Table A2.9: Basic Cost and Performance Characteristics for Conventional Generation

\begin{tabular}{|c|c|c|c|c|c|}
\hline Type & Install Date & $\begin{array}{c}\text { Capital Cost } \\
\$ / \mathbf{k W}^{*}\end{array}$ & $\begin{array}{c}\text { Fixed O\&M } \\
\$ / M W-y r\end{array}$ & $\begin{array}{c}\text { Var O\&M } \\
\$ / M W h\end{array}$ & $\begin{array}{c}\text { Heat rate } \\
\text { MMBTU/MWh }\end{array}$ \\
\hline \multirow[t]{7}{*}{ Gas-CT } & 2000 & 504 & 8,415 & 3.16 & 10.82 \\
\hline & 2005 & 407 & 10,315 & 3.07 & 10.03 \\
\hline & 2010 & 386 & 10,315 & 3.07 & 9.50 \\
\hline & 2020 & 358 & 10,315 & 3.07 & 9.50 \\
\hline & 2030 & 351 & 10,315 & 3.07 & 9.50 \\
\hline & 2040 & 351 & 10,315 & 3.07 & 9.50 \\
\hline & 2050 & 351 & 10,315 & 3.07 & 9.50 \\
\hline \multirow[t]{7}{*}{ Gas-CC } & 2000 & 626 & 10,527 & 2.10 & 7.20 \\
\hline & 2005 & 584 & 11,021 & 1.85 & 6.97 \\
\hline & 2010 & 568 & 11,021 & 1.85 & 6.57 \\
\hline & 2020 & 537 & 11,021 & 1.85 & 6.57 \\
\hline & 2030 & 527 & 11,021 & 1.85 & 6.57 \\
\hline & 2040 & 527 & 11,021 & 1.85 & 6.57 \\
\hline & 2050 & 527 & 11,021 & 1.85 & 6.57 \\
\hline \multirow{7}{*}{$\begin{array}{l}\text { Existing Coal } \\
\text { (Scrubbed) } \\
\text { (see note \# 7) }\end{array}$} & 2000 & $\mathrm{~N} / \mathrm{A}$ & 23,410 & 3.40 & 10 \\
\hline & 2005 & $\mathrm{~N} / \mathrm{A}$ & 25,847 & 3.75 & 10 \\
\hline & 2010 & 204 & 28,537 & 4.14 & 10 \\
\hline & 2020 & 204 & 34,786 & 5.05 & 10 \\
\hline & 2030 & 204 & 42,404 & 6.16 & 10 \\
\hline & 2040 & 204 & 51,690 & 7.51 & 10 \\
\hline & 2050 & 204 & 63,010 & 9.15 & 10 \\
\hline \multirow{7}{*}{$\begin{array}{l}\text { Existing Coal } \\
\text { (Unscrubbed) }\end{array}$} & 2000 & $\mathrm{~N} / \mathrm{A}$ & 27,156 & 3.94 & 10 \\
\hline & 2005 & $\mathrm{~N} / \mathrm{A}$ & 29,982 & 4.35 & 10 \\
\hline & 2010 & N/A & 33,103 & 4.81 & 10 \\
\hline & 2020 & N/A & 40,352 & 5.86 & 10 \\
\hline & 2030 & $\mathrm{~N} / \mathrm{A}$ & 49,189 & 7.14 & 10 \\
\hline & 2040 & N/A & 59,961 & 8.71 & 10 \\
\hline & 2050 & N/A & 73,092 & 10.62 & 10 \\
\hline \multirow[t]{7}{*}{ Coal-new } & 2000 & 1,249 & 25,091 & 4.18 & 8.84 \\
\hline & 2005 & 1,249 & 25,091 & 4.18 & 8.84 \\
\hline & 2010 & 1,232 & 25,091 & 4.18 & 8.67 \\
\hline & 2020 & 1,193 & 25,091 & 4.18 & 8.6 \\
\hline & 2030 & 1,176 & 25,091 & 4.18 & 8.6 \\
\hline & 2040 & 1,176 & 25,091 & 4.18 & 8.6 \\
\hline & 2050 & 1,176 & 25,091 & 4.18 & 8.6 \\
\hline \multirow[t]{6}{*}{ Coal-IGCC } & 2000 & 1,444 & 25,091 & 2.58 & 8.31 \\
\hline & 2005 & 1,444 & 25,091 & 2.58 & 8.31 \\
\hline & 2010 & 1,406 & 25,091 & 2.58 & 7.52 \\
\hline & 2020 & 1,305 & 25,091 & 2.58 & 7.2 \\
\hline & 2030 & 1,182 & 25,091 & 2.58 & 7.2 \\
\hline & 2040 & 1,182 & 25,091 & 2.58 & 7.2 \\
\hline
\end{tabular}




\begin{tabular}{|lccccc|} 
& 2050 & 1,182 & 25,091 & 2.58 & 7.2 \\
\hline Oil/gas/steam & 2000 & $\mathrm{~N} / \mathrm{A}$ & 25,256 & 3.16 & 9 \\
& 2005 & $\mathrm{~N} / \mathrm{A}$ & 27,884 & 3.49 & 9.23 \\
& 2010 & $\mathrm{~N} / \mathrm{A}$ & 30,786 & 3.85 & 9.46 \\
& $\mathrm{~N} / \mathrm{A}$ & 37,528 & 4.70 & 9.94 \\
& 2020 & $\mathrm{~N} / \mathrm{A}$ & 45,747 & 5.73 & 10.45 \\
& 2030 & $\mathrm{~N} / \mathrm{A}$ & 55,765 & 6.98 & 10.99 \\
& 2040 & $\mathrm{~N} / \mathrm{A}$ & 67,978 & 8.51 & 11.55 \\
\hline Nuclear & 2050 & 2016 & 61,862 & 0.45 & 10.4 \\
& 2000 & 2016 & 61,862 & 0.45 & 10.4 \\
& 2005 & 1958 & 61,862 & 0.45 & 10.4 \\
& 2010 & 1862 & 61,862 & 0.45 & 10.4 \\
& 2020 & 1814 & 61,862 & 0.45 & 10.4 \\
& 2030 & 1814 & 61,862 & 0.45 & 10.4 \\
& 2040 & 1814 & 61,862 & 0.45 & 10.4 \\
\hline
\end{tabular}

Source: U.S. DOE. 2005c.

Fossil capital costs: Table 48 (Reference Case)

Fossil heat Rates: Table 48 (Reference Case)

Nuclear capital cost: Table 49 (Reference Case)

Fixed and Variable O\&M: Table 38

\section{Notes:}

1) Capital costs are "overnight" costs, not including interest during construction

2) The current AEO projects costs every 5 years to 2025. Values in WinDS are interpolated linearly to derive the even year values. Values beyond 2025 are assumed to be constant.

3) Cost values and heat rates for the Gas-CT and Gas-CC are based on the average of the "conventional" and "advanced" cases in the AEO.

4) New nuclear may not be constructed before 2010.

5) Old coal and oil/gas/steam may not be constructed in WinDS.

6) Costs are adjusted to $\$ 2004$.

7) This value represents the cost of converting unscrubbed to scrubbed coal.

8) $O \& M=$ operation and maintenance. $O \& M$ costs do not include fuel.

9) Heat rate is net heat rate (including internal plant loads).

10) Values are interpolated for intermediate years in WinDS.

\subsection{Capital Cost Adjustment Factors}

Interest during construction can increase the effective capital cost for each technology. Table A2.10 indicates the construction time and schedule for each conventional technology. 
Table A2.10: Capital Cost Adjustment Factors

\begin{tabular}{|l|c|c|}
\hline & $\begin{array}{c}\text { Construction } \\
\text { Time }\end{array}$ & Schedule \\
\hline Hydro & NA & NA \\
\hline Gas-CT & 3 & A \\
\hline Gas-Combined Cycle (CC) & 3 & C \\
\hline Coal-old-1 (Scrubbed) & $\begin{array}{c}\text { 3 (add scrubber } \\
\text { to existing) }\end{array}$ & A \\
\hline Coal-old-2 (Uncrubbed) & NA & NA \\
\hline Coal-new & 4 & D \\
\hline Coal-IGCC & 4 & D \\
\hline Oil/gas/steam (o-g-s) & NA & NA \\
\hline Nuclear & 6 & B \\
\hline Geothermal & NA & NA \\
\hline Biopower & NA & NA \\
\hline Concentrating Solar (CSP) & 3 & C \\
\hline Landfill Gas (Ifill-gas) & NA & NA \\
\hline
\end{tabular}

Notes:

1) Construction time source: U.S. DOE. 2005a. Table 38.

2) Schedule refers to the fraction of capital cost that must be committed each year during construction. This is used to calculate interest, and the total capital cost required to build each plant. Assumed schedules are in Table A2.11.

Table A2.11: Generator Construction Schedules

\begin{tabular}{|l|c|c|c|c|c|c|}
\hline & \multicolumn{7}{|c|}{ Fraction of Cost in Each Year } \\
\hline Schedule & 1 & 2 & 3 & 4 & 5 & 6 \\
\hline A & $80 \%$ & $10 \%$ & $10 \%$ & & & \\
\hline B & $10 \%$ & $20 \%$ & $20 \%$ & $20 \%$ & $20 \%$ & $10 \%$ \\
\hline C & $50 \%$ & $40 \%$ & $10 \%$ & & & \\
\hline D & $40 \%$ & $30 \%$ & $20 \%$ & $10 \%$ & & \\
\hline
\end{tabular}

\subsection{Outage Rates (Forced Outage and Planned Outage)}

WinDS considers the outage rate when determining the net capacity available for energy generation and in determining the capacity value of each technology. Planned outages are assumed to occur in all seasons except the summer. Table A2.12 provides the outage rate for each conventional technology. 
Table A2.12: Conventional Generator Outage Rates

\begin{tabular}{|l|c|c|}
\hline Generator Type & $\begin{array}{c}\text { Forced } \\
\text { Outage Rate } \\
(\mathbf{\%})\end{array}$ & $\begin{array}{c}\text { Planned } \\
\text { Outage Rate } \\
(\mathbf{\%})\end{array}$ \\
\hline Hydro & 2.0 & 5.0 \\
\hline Gas-CT & 10.7 & 6.4 \\
\hline Gas-Combined Cycle (CC) & 5.0 & 7.0 \\
\hline Existing Coal (Scrubbed) & 7.9 & 9.8 \\
\hline Existing Coal (Unscrubbed) & 7.9 & 9.8 \\
\hline Coal-new & 7.9 & 9.8 \\
\hline Coal-IGCC & 7.9 & 9.8 \\
\hline Oil/gas/steam (o-g-s) & 7.9 & 9.8 \\
\hline Nuclear & 5.0 & 5.0 \\
\hline
\end{tabular}

Source: National Electric Reliability Council's (NERC) Generating Availability Data System (GADS) http://www.nerc.com/ gads/ Planned outage rate based on SOF (scheduled outage hours divided by total hours). Forced outage rate based on EFORd (Equivalent Forced Outage Rate demand). Derived from a data run by Mike Curley of NERC (3/12/03).

\subsection{Emission Rates}

Emission rates are estimated for $\mathrm{SO}_{2}, \mathrm{NOx}$, Mercury $(\mathrm{Hg})$, and $\mathrm{CO}_{2}$. Table A2.13 provides the input emission rates for (lbs/MMBTU of input fuel) plants that use combustible fuel. Output emission rates $(\mathrm{lb} / \mathrm{MWh})$ may be calculated by multiplying input emission rate by heat rate.

Table A2.13: Input Emissions Rates (Ibs/MMBTU fuel input)

\begin{tabular}{|l|c|c|c|c|}
\hline & SO2 & NOx & $\begin{array}{c}\text { Mercury } \\
(\mathbf{H g})\end{array}$ & $\mathbf{C O 2}$ \\
\hline Hydro & 0 & 0 & 0 & 0 \\
\hline Gas-CT & 0.0034 & 0.08 & 0 & 122.1 \\
\hline Gas-Combined Cycle (CC) & 0.0034 & 0.02 & 0 & 122.1 \\
\hline Existing Coal (Scrubbed) & 0.26 & 0.448 & 0.0000046 & 207.3 \\
\hline Existing Coal (Uncrubbed) & 1.7 & 0.448 & 0.0000046 & 207.3 \\
\hline Coal-new & 0.09 & 0.02 & 0.0000046 & 207.3 \\
\hline Coal-IGCC & 0.04 & 0.02 & 0.0000046 & 122.1 \\
\hline Oil/gas/steam (o-g-s) & 0 & 0.1 & 0 & 122.1 \\
\hline Nuclear & 0 & 0 & 0 & 0 \\
\hline Biopower & 0 & 0 & 0 & 0 \\
\hline Concentrating Solar (CSP) & 0.0065 & 0.02 & 0 & 30.5 \\
\hline Landfill Gas (Ifill-gas) & 0.045 & 0 & 0 & 0 \\
\hline
\end{tabular}

\section{Sources and Notes:}

1) $\mathrm{SO}_{2}: \mathrm{SO}_{2}$ emissions result from the oxidization of sulfur contained in the fuel. Natural gas rate source: U.S. EPA. 1996, (AP-42 Section 3.1 Stationary Gas Turbines). $\mathrm{SO}_{2}$ input emissions rate for coal is based on the fuel content of the fuel and the use of post-combustion controls. The "base" emissions rate for existing and new conventional coal plants is based on a national average sulfur content of $0.9 \mathrm{lbs} / \mathrm{MMBTU}(1.8 \mathrm{lb} \mathrm{SO} 2 / \mathrm{mmBTU})$. WinDS assumes the national average for "low sulfur" coal is $0.5 \mathrm{lbs} \mathrm{SO}_{2} / \mathrm{MMBTU}$. Values based on national averages from AEO Assumptions (2005), Table 73. Scrubber removal efficiency is assumed to be $85 \%$ for retrofits, 95\% for new plants (U.S. EPA. 1996 AP-42 Section 1.1.4 Controls). 
2) $\mathrm{CO}_{2}: \mathrm{CO}_{2}$ emissions result from the oxidization of carbon in the fuel and emissions rate is based solely on fuel type, and therefore constant for all plants burning the same fuel type. All emissions are point-source emissions from the plant only (not "life-cycle" emissions). Natural gas emission rate are from U.S. EPA 1996, (AP-42 Section 3.1 Stationary Gas Turbines). $\mathrm{CO}_{2}$ content for coal is based on the national average from AEO Assumptions (U.S. DOE 2005c), Table 73. Biofuels are assumed to be carbon neutral. Landfill gas is assumed to have zero carbon emissions, because the gas would be flared otherwise. CSP plants burn a small amount of natural gas, resulting in $\mathrm{CO}_{2}$ emissions. $\mathrm{CO}_{2}$ emissions are not constrained in the WinDS base case.

\subsection{Fuel Prices}

Fuel prices for natural gas and coal are derived from projections from the AEO 2005 (U.S. DOE. 2005b -Energy Prices by Sector and Source). These tables provide the prices in each census region, which are then assigned to a NERC subregion used in WinDS. Prices in the AEO are projected to 2025. Beyond 2025, WinDS increases fuel prices at the same national annual average rate as projected by the AEO between 2015 and 2025 .

Figure A2.3 illustrates the projected fossil fuel prices in constant 2004\$. The prices are projected out to 2070, because WinDS attempts to design a cost-optimal system over an evaluation horizon of 20 years. Values to the right of the vertical line in Figure A2.3 (at 2025) are extrapolation of EIA fuel price projections. (Averages shown on graph do not reflect the "real" average, which would be weighted by sales, but are the average weighted by region.)

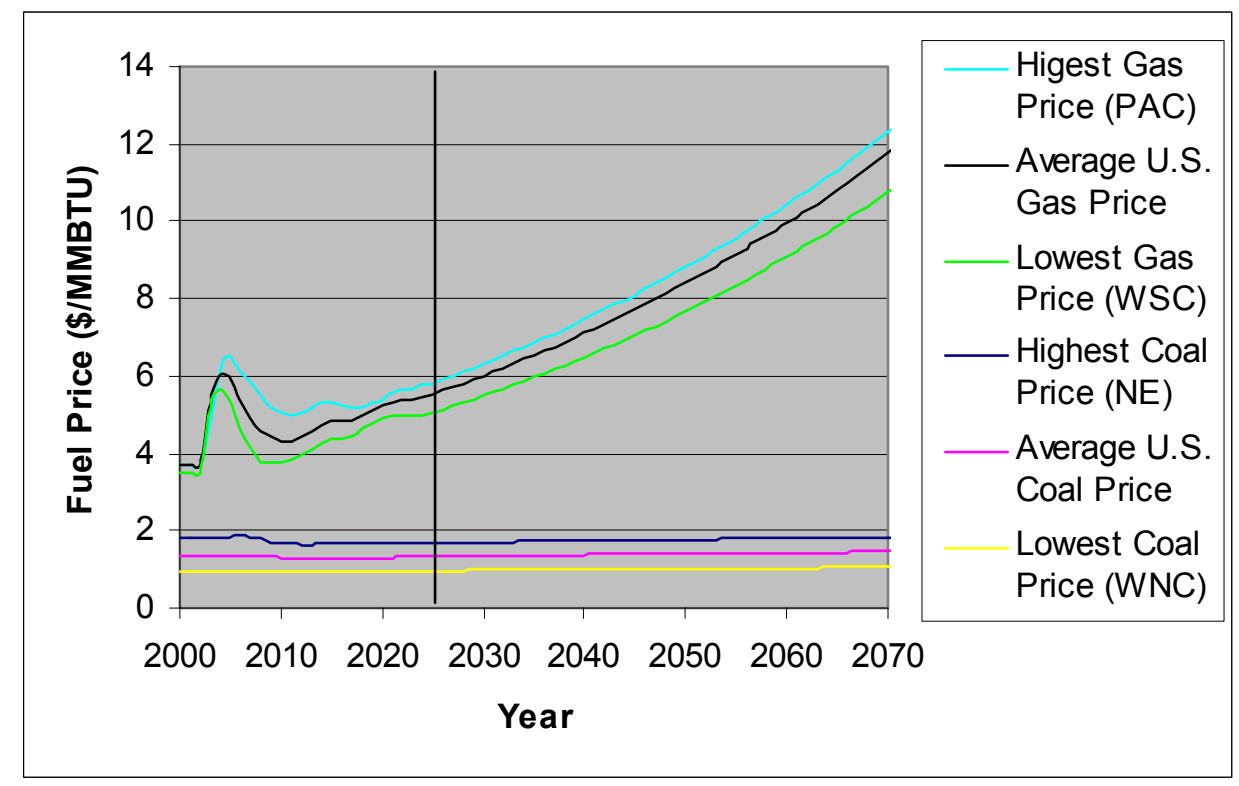

Figure A2.3: Projected Coal and Natural Gas Prices in WinDS to 2080

Uranium fuel price in WinDS is constant at \$0.4/MMBTU (U.S. DOE. 2003, pg 68). 


\section{6) Federal and State Energy Policy}

\subsection{Federal Emission Standards}

$\mathrm{CO}_{2}$ : WinDS has the ability to add a national cap on $\mathrm{CO}_{2}$ emissions from electricity, or a $\mathrm{CO}_{2}$ emission charge (tax). Neither a carbon cap nor charge is implemented in the base case.

$\mathrm{SO}_{2}$ : Emissions of $\mathrm{SO}_{2}$ are capped at the national level. WinDS uses a cap established by the 1990 Clean Air Act Amendments.

\subsection{Federal Energy Incentives}

There are several classes of incentives applied at the federal level. These incentives generally have the effect of reducing the cost of providing energy from an incentivized source. A production tax credit (PTC) provides an offset to the tax liability of companies, based on the production of energy from an incentivized source; an investment tax credit provides an offset to tax liability, based on investment in an incentivized source.

Table A2.14: Federal Renewable Energy Incentives

\begin{tabular}{|l|l|l|}
\hline Name & Value & Notes \& Source \\
\hline $\begin{array}{l}\text { Renewable Energy } \\
\text { PTC }\end{array}$ & $\begin{array}{l}\text { A18/MWh } \\
\text { of incentive. Value is adjusted for inflation. Expires } \\
\text { end of 2007 }\end{array}$ \\
\hline
\end{tabular}

Source: U.S. Congress 2005

\subsection{State Energy Incentives}

Several states also have production and investment incentives for renewable energy sources. The values used in WinDS are listed in Table A2.15.

Table A2.15: State Renewable Energy Incentives

\begin{tabular}{|c|c|c|c|}
\hline State & $\begin{array}{c}\text { PTC } \\
\text { \$/MWh }\end{array}$ & ITC & $\begin{array}{c}\text { Assumed State } \\
\text { Corporate Tax } \\
\text { Rate }\end{array}$ \\
\hline IA & & $5.00 \%$ & $10.0 \%$ \\
\hline ID & & $5.00 \%$ & 7.60 \\
\hline MN & & $6.50 \%$ & $9.8 \%$ \\
\hline NJ & & $6.00 \%$ & $9.0 \%$ \\
\hline NM & 10 & & $7.0 \%$ \\
\hline OK & 2.5 & & $6.0 \%$ \\
\hline UT & & $4.75 \%$ & $5.0 \%$ \\
\hline WY & & $4.00 \%$ & $9.0 \%$ \\
\hline
\end{tabular}

Tax rates from: http://www.taxadmin.org/fta/rate/corp_inc.html 


\subsection{Federal Renewable Portfolio Standards}

A renewable portfolio standard (RPS) requires that a certain fraction of a region's energy be derived from renewable energy. While there is no federal RPS in place (as of March 2006), WinDS can accommodate a national RPS, with input values for fraction of energy to be provided by renewables, RPS start year, duration, and shortfall penalty.

\subsection{State Renewable Portfolio Standards}

There are several states that currently have RPS policies. States may have capacity mandates as an alternative or supplement to an RPS. A capacity mandate requires a utility to install a certain fixed capacity of renewable energy generation.

Table A2.16: State Renewable Portfolio Standard (RPS)

\begin{tabular}{|c|c|c|c|c|}
\hline State & $\begin{array}{c}\text { RPS Start } \\
\text { Year }^{1}\end{array}$ & $\begin{array}{c}\text { Penalty in } \\
\text { \$/MWh }\end{array}$ & $\begin{array}{c}\text { RPS } \\
\text { Fraction }^{2}\end{array}$ & $\begin{array}{c}\text { Load } \\
\text { Fraction }^{3}\end{array}$ \\
\hline AZ & 2025 & 50 & 0.079 & 1 \\
\hline CA & 2017 & 5 & 0.034 & 0.63 \\
\hline CO & 2015 & 50 & 0.044 & 0.69 \\
\hline CT & 2010 & 55 & 0.013 & 0.94 \\
\hline DE & 2019 & 25 & 0.056 & 0.75 \\
\hline IL & 2013 & 10 & 0.062 & 0.92 \\
\hline MA & 2009 & 50 & 0.026 & 0.85 \\
\hline MD & 2019 & 20 & 0.045 & 0.8 \\
\hline MN & 2015 & 10 & 0.071789 & 1 \\
\hline MT & 2015 & 10 & 0.075 & 0.9 \\
\hline NJ & 2008 & 50 & 0.029 & 1 \\
\hline NM & 2011 & 10 & 0.026 & 0.53 \\
\hline NV & 2015 & 10 & 0.133 & 0.89 \\
\hline NY & 2013 & 5 & 0.035 & 0.84 \\
\hline OK & 2016 & 50 & 0.05 & 1 \\
\hline OR & 2020 & 5 & 0.078 & 1 \\
\hline PA & 2020 & 45 & 0.014 & 0.98 \\
\hline RI & 2019 & 55 & 0.069 & 0.99 \\
\hline TX & 2009 & 50 & 0.01 & 1 \\
\hline VT & 2012 & 10 & 0.05 & 1 \\
\hline WI & 2011 & 10 & 0.006 & 0.75 \\
\hline
\end{tabular}

\section{Notes:}

1) RPS Start Year is the year that the "fraction" or mandate must be met

2) RPS Fraction is the fraction of state demand that must be met by renewables by the start year. This value is adjusted to estimate the fraction actually provided by wind, because WinDS does not currently include other renewables such as biomass cofiring, certain hydro projects, etc.

3) Load fraction is the fraction of the total state load that must meet the RPS. In certain locations, municipal or cooperative power systems may be exempt from the RPS. 


\section{7) References for Appendix 2}

Elliott, D.L. and M.N. Schwartz, 1993. "Wind Energy Potential in the United States." PNL-SA-23109. Richland, WA: Pacific Northwest Laboratory. NTIS No. DE94001667.

McDonald, Alan and L. Schrattenholzer, 2001. "Learning rates for energy technologies," Energy Policy, Vol 29, pp 255-261.

U.S. Department of Energy (DOE), 2003. "Annual Energy Outlook, With Projections to 2025”, Energy Information Administration, DOE/EIA-0383(2003), www.eia.doe.gov/oiaf/aeo/, February.

U.S. DOE, 2003b. "Analysis of S. 485, the Clear Skies Act of 2003, and S. 843, the Clean Air Planning Act of 2003," Energy Information Administration, SR/OIAF200303(2003), September.

U.S. DOE, 2005a. “Annual Energy Outlook, With Projections to 2025," Energy Information Administration, DOE/EIA-0383(2005), www.eia.doe.gov/oiaf/aeo/, February.

U.S. DOE, 2005b. "Supplemental Tables to the Annual Energy Outlook," Energy Information Administration, http://www.eia.doe.gov/oiaf/aeo/supplement/index.html

U.S. DOE, 2005c. "Assumptions to the Annual Energy Outlook," Energy Information Administration, www.eia.doe.gov/oiaf/aeo/assumption/pdf/0554\{2005\}.pdf

U.S. Environmental Protection Agency (EPA), 1996. "Compilation of Air Pollutant Emission Factors, AP-42," Fifth Edition, Volume I: Stationary Point and Area Sources. U.S. EPA. http://www.epa.gov/ttn/chief/ap42/

U.S. EPA, 2005. “eGRID Emissions \& Generation Resource Integrated Database,” U.S. EPA Office of Atmospheric Programs, http://www.epa.gov/cleanenergy/egrid/index.htm

U.S. Congress, 2005. "Domenici-Barton Energy Policy Act of 2005," Washington, D.C. $109^{\text {th }}$ Congress, July 2005. 


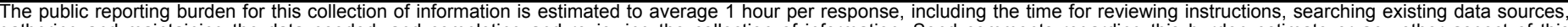

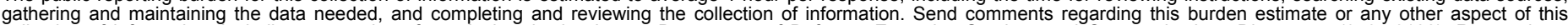

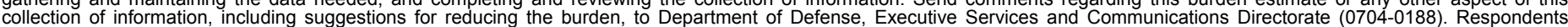

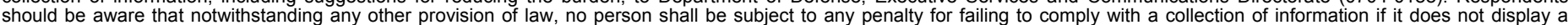

currently valid OMB control number.

PLEASE DO NOT RETURN YOUR FORM TO THE ABOVE ORGANIZATION.
1. REPORT DATE (DD-MM-YYYY) April 2006
4. TITLE AND SUBTITLE
A Preliminary Assessment of Plug-in Hybrid Electric Vehicles on
Wind Energy Markets

3. DATES COVERED (From - To)

5a. CONTRACT NUMBER

DE-AC36-99-G010337

5b. GRANT NUMBER

5c. PROGRAM ELEMENT NUMBER

5d. PROJECT NUMBER

NREL/TP-620-39729

5e. TASK NUMBER

WUA7.1000

5f. WORK UNIT NUMBER
7. PERFORMING ORGANIZATION NAME(S) AND ADDRESS(ES)

National Renewable Energy Laboratory

1617 Cole Blvd.

Golden, CO 80401-3393
8. PERFORMING ORGANIZATION REPORT NUMBER

NREL/TP-620-39729

9. SPONSORING/MONITORING AGENCY NAME(S) AND ADDRESS(ES)

10. SPONSOR/MONITOR'S ACRONYM(S) NREL

11. SPONSORING/MONITORING AGENCY REPORT NUMBER

12. DISTRIBUTION AVAILABILITY STATEMENT

National Technical Information Service

U.S. Department of Commerce

5285 Port Royal Road

Springfield, VA 22161

13. SUPPLEMENTARY NOTES

14. ABSTRACT (Maximum 200 Words)

This report examines a measure that may potentially reduce oil use and also more than proportionately reduce carbon emissions from vehicles. The authors present a very preliminary analysis of plug-in hybrid electric vehicles (PHEVs) that can be charged from or discharged to the grid. These vehicles have the potential to reduce gasoline consumption and carbon emissions from vehicles, as well as improve the viability of renewable energy technologies with variable resource availability. This paper is an assessment of the synergisms between plug-in hybrid electric vehicles and wind energy. The authors examine two bounding cases that illuminate this potential synergism.

15. SUBJECT TERMS

plug-in hybrid electric vehicle; PHEV; analysis; transportation; carbon emissions; energy; oil; gasoline; fuel; fuelefficient vehicles; wind energy; Wind Deployment System model; WinDS; Walter Short; Paul Denholm

\begin{tabular}{|c|c|c|c|c|}
\hline \multicolumn{3}{|c|}{ 16. SECURITY CLASSIFICATION OF: } & \multirow{2}{*}{$\begin{array}{l}\text { 17. LIMITATION } \\
\text { OF ABSTRACT } \\
\text { UL }\end{array}$} & \multirow{2}{*}{$\begin{array}{l}\text { 18. NUMBER } \\
\text { OF PAGES }\end{array}$} \\
\hline $\begin{array}{l}\text { a. REPORT } \\
\text { Unclassified }\end{array}$ & $\begin{array}{l}\text { b. ABSTRACT } \\
\text { Unclassified }\end{array}$ & $\begin{array}{l}\text { c. THIS PAGE } \\
\text { Unclassified }\end{array}$ & & \\
\hline
\end{tabular}
19a. NAME OF RESPONSIBLE PERSON 19b. TELEPHONE NUMBER (Include area code) 